\title{
norden
}

\section{Kreativitet, innovasjon og entreprenørskap}

- Perspektiv på naturvitenskapelig talent og praktisk-musiske fag 
4 nordon 



\section{Kreativitet, innovasjon og entreprenørskap}

Perspektiv på naturvitenskapelig talent og praktisk-musiske fag

Gerd Abrahamsen, Lise-Kari Berg, Espen Henriksen

og Jarle Sjøvoll

TemaNord 2011:520 
Kreativitet, innovasjon og entreprenørskap

Perspektiv på naturvitenskapelig talent og praktisk-musiske fag

TemaNord 2011:520

Omslagsfoto: Johannes Jansson

(C) Nordisk ministerråd, København 2011

ISBN 978-92-893-2208-9

Denne rapporten er gitt ut med finansiell støtte fra Nordisk ministerråd. Innholdet i rapporten avspeiler imidlertid ikke nødvendigvis Nordisk ministerråds synspunkter, holdninger eller anbefalinger.

Nordisk ministerråd

Ved Stranden 18

DK-1061 København K

Telefon (+45) 33960200

Fax (+45) 33960202

\section{Nordisk råd}

Ved Stranden 18

DK-1061 København K

Telefon (+45) 33960400

Fax (+45) 33111870

www.norden.org

\section{Det nordiske samarbeidet}

Det nordiske samarbeid er en av verdens mest omfattende regionale samarbeidsformer. Samarbeidet omfatter Danmark, Finland, Island, Norge og Sverige, samt de selvstyrende områdene Færøyene, Grønland og Åland.

Det nordiske samarbeid er både politisk, økonomisk og kulturelt forankret, og er en viktig medspiller i det europeiske og internasjonale samarbeid. Det nordiske fellesskap arbeider for et sterkt Norden i et sterkt Europa.

Det nordiske samarbeid ønsker å styrke nordiske og regionale interesser og verdier i en global omverden. Felles verdier landene imellom er med til å styrke Nordens posisjon som en av verdens mest innovative og konkurransekraftige regioner. 


\section{Innhold}

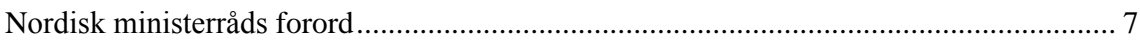

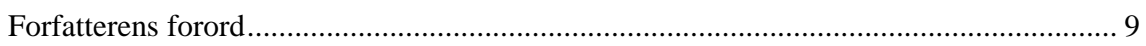

1. Kreativitet, innovasjon og entreprenørskap i utdannings-systemene i Norden .............. 11

1.1 I denne studien tas det utgangspunkt i hovedproblemstillingen: .......................... 11

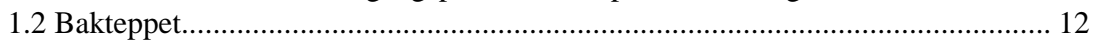

1.3 Kreativitet, innovasjon og entreprenørskap ...................................................... 14

1.4 Pedagogisk entreprenørskap............................................................................ 16

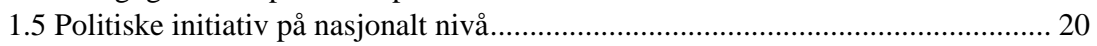

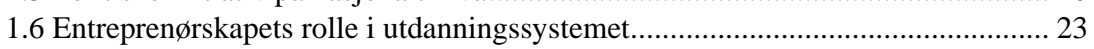

1.7 Aktører utenfor utdanningssystemet................................................................ 27

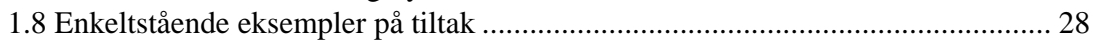

1.9 Eksempler på globale problemstillinger - konkrete utfordringer ......................... 29

1.10 Noen råd om nordisk samarbeid ....................................................................... 31

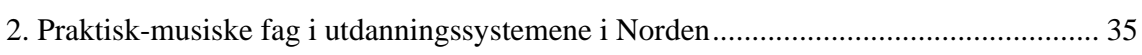

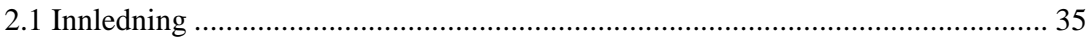

2.2 Begrepene kreativitet, innovasjon og entreprenørskap ..................................... 37

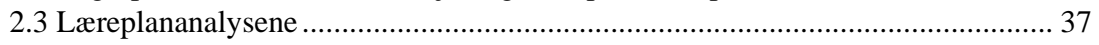

2.4 Råd om tiltak ................................................................................................. 41

3. Utvikling av naturvitenskapelig talent og kreativitet i Norden ....................................... 43

3.1 Hvilke krav stilles i læreplanene om å ivareta talentutvikling? ............................ 43

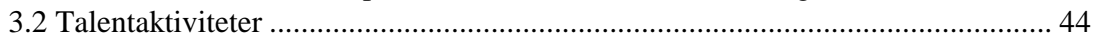

3.3 Holdning til talentutvikling ............................................................................ 46

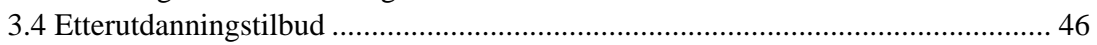

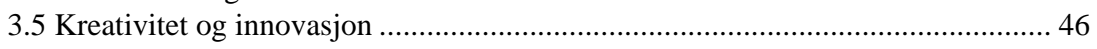

3.6 Etterutdanning innenfor kreativitet og innovasjon ............................................. 47

4. Avsluttende kommentarer og forslag til tiltak ......................................................... 49 



\section{Nordisk ministerråds forord}

En kunnskapsrik, kreativ og innovativ befolkning er en forutsetning for bæredyktig vekst og en videre utvikling av våre lands velferd. Grunnlaget for disse kompetansene legges i tidlig alder, og det er derfor viktig at skolen og utdanningen fra dag én fremmer kreativitet, innovasjon og entreprenørskap.

En opplæring preget av høy faglig kvalitet og der kreativitet, innovasjon og entreprenørskap er en naturlig del av undervisningen, vil også kunne gi «tilleggseffekter» i form av økt motivasjon, trivsel, redusert fravær og bidra til å forebygge frafall.

I arbeidslivet er arbeidstakernes evne og vilje til kreativitet, innovasjon og entreprenørskap avgjørende for bedriftenes innovasjon og konkurranseevne.

De nordiske undervisnings- og forskningsministre ønsker å fremme kreativitet, innovasjon og entreprenørskap i utdannelsene. Dette var bakgrunnen for at ministrene i april 2009 besluttet at Nordisk ministerråd skulle gjennomføre en nordisk komparativ studie av hvordan kreativitet, innovasjon og entreprenørskap er integrert i de nordiske utdanningssystemene.

Som tilleggsoppdrag til denne studien, ble det i 2010 under det danske formannskapet i Nordisk ministerråd, tatt initiativ til ytterligere to studier om henholdsvis de praktisk musiske fag og de nordiske lands arbeid med talentutvikling og kreativitet i relasjon til naturvitenskap.

De tre studiene foreligger nå, og det er Nordisk ministerråds ønske at de tre studiene kan være til inspirasjon for alle i Norden, som arbeider med disse temaene.

Studiene er en del av Nordisk ministerråds globaliseringsprosjekt «En god opplæring til ungdom og voksne» som har som ett av fire delmål å fremme kreativitet, innovasjon og entreprenørskap i utdanningen.

God lesing!

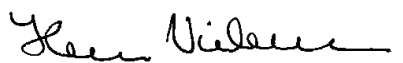

Henna Virkkunen

Undervisningsminister 



\section{Forfatterens forord}

Dette er en sammenfatning av 3 studier initiert av Nordisk ministerråd (NMR). Hovedstudien er en kartlegging av status for hvordan kreativitet, innovasjon og entreprenørskap er omtalt i styringsdokumenter og realisert i opplæringa på alle nivå, fra barnehage til voksenopplæring, i de nordiske landene inkludert de selvstyrte områdene. Det er ut over dette gjennomført to tilleggsoppdrag. I denne sammenfattede rapporten presenteres noen av resultatene fra disse tre studiene. Dette gjelder:

- Hovedstudie om kreativitet, innovasjon og entreprenørskap i utdanningen

- En studie om praktisk-musiske fag (tilleggsstudie 1)

- En studie om talentutvikling og kreativitet i naturvitenskapelige fag (tilleggsstudie 2)

Disse korte sammenfatningene bygger på informasjon som er utredet og formidlet i rapporter rapportene fra de tre studiene som ble gjennomført i 2010. Sammenfatningene er skrevet av Jarle Sjøvoll (hovedstudie), Gerd Abrahamsen og Lise-Kari Berg (tilleggsstudie 1) og Espen Henriksen (tilleggsstudie 2). Alle tilsatt ved det nye Universitetet i Nordland.

Studien er en del av prosjektet «En god opplaring for ungdom og voksne», som er ett av prosjektene Nordisk ministerråd satte i gang i 2007/2008 gjennom det nordiske samarbeidet. Den overordnede målsetning med prosjektet «En god opplæring for ungdom og voksne» er å få flere ungdommer enn i dag til å fullføre utdanning etter grunnskolen, samt å fremme voksnes kunnskaper og kompetanse som grunnlag for personlig utvikling og inkludering i arbeids- og samfunnsliv.

Sammenfatningene inneholder korte beskrivelser og vurdering av den aktuelle situasjonen i utdanningssystemene i de nordiske landene. Det er derfor nødvendig å lese oversiktsrapportene fra hver studie for å få et dypere innblikk i rapportene om situasjonen i hvert land. Sammenfatningene for alle rapportene tar utgangspunkt i spørsmålene slik de er utformet i mandat og problemstillinger i oppdragsdokumentene.

Bodø, februar 2011

Jarle Sjøvoll 



\section{Kreativitet, innovasjon og entreprenørskap i utdannings- systemene i Norden}

Sammenfatning av hovedstudien

Jarle Sjøvoll

\subsection{I denne studien tas det utgangspunkt i hovedproblemstillingen:}

Hvordan er kreativitet, innovasjon og entreprenørskap integrert i barnehage/ førskole, grunnskole og videregående opplæring (ungdomsutbildningen) samt voksenopplæringen og i lærerutdanningen i de nordiske landene inkludert de selvstyrte områdene (Åland, Færøyane og Grønland).

Studiens tema kreativitet, innovasjon og entreprenørskap relateres til aktuelle forhold i globaliseringens tid. Nordisk ministerråd (NMR) ønsket å få beskrevet og vurdert sammenhengen mellom kreativitet, innovasjon og entreprenørskap i lys av globaliseringens utfordringer. I den grad det er relevant skal initiativ som er tatt av EU og andre internasjonale fora innenfor dette temaområdet trekkes inn og vurderes.

Denne sammenfatningen bygger på momenter som er utredet i studiene fra hvert av de nordiske landene inkludert de selvstyrte områdene. Studien er utført for Nordisk ministerråd av et forskerteam ledet av Universitetet i Nordland (tidligere Høgskolen i Bodø). Utredningsteamet var satt sammen av forskere fra de nordiske landene. Oppdraget var å kartlegge utviklingen av kreativitet, innovasjon og entreprenørskap, relatert til utdanning, i de nordiske landene. Hensikten med denne rapporten er å gi et bilde av initiativ som er tatt for å fremme kreativitet, innovasjon og entreprenørskap i de nordiske utdanningssystemene, fra politisk nivå til realisering i praksis. Studien er i hovedsak basert på analyse av tekster; politiske dokumenter, forskningsrapporter og undersøkelser, dokumenterte utviklingsprosjekter og intervjuer.

Studien er utført med referanse til forskningsspørsmålene slik framgår eksplisitt eller er utledet av hovedproblemstillingen. Noen av disse spørsmålene vektlegges sterkere enn andre i denne sammenfatningen, men den utfyllende beskrivelsen og drøftingen som relaterer seg til aktu- 
elle forhold i hvert enkelt land berøres i hovedsak i kapitlene som omhandler det enkelte land i rapporten fra hovedstudien.

\subsection{Bakteppet}

I rapporten «Towards an enterprising culture - a challenge for education and training» (OECD/CERI 1989), framgår at det i nesten alle medlemslandene er et økende antall utøvere, offentlige og private, som arbeider for å styrke den entreprenørielle kompetansen hos enkeltpersoner og i samfunnet som helhet. Det pekes spesielt på viktigheten av at utdanning blir viet spesiell oppmerksomhet, og at et gjensidig forhold mellom utdanning og næringsliv må fungere godt i et raskt skiftende samfunn. Det ble i rapporten konkludert med at endringer på alle områder i et menneskes liv og samfunnets institusjoner, organisasjoner og kultur fører til et økende behov for at mange etablerer seg som gründere. Utdanningssystemets innovasjonskapasitet og entreprenørielle kompetanse kom ved dermed sterkt $i$ fokus på grunnlag av dette politiske og økonomiske initiativ.

\subsubsection{Utgangspunkt i Lisboa-strategien}

Det europeiske råd sitt innspill under møtet i mars 2000 i Lisboa, der man diskuterte unionens strategiske mål for det neste tiåret, fikk også stor betydning. De nye visjonene og målene innebar at EU skulle arbeide for å bli verdens mest dynamiske, konkurransedyktige og kunnskapsbaserte økonomi. En økonomi som skulle være i stand til å oppnå en bærekraftig vekst med flere og bedre arbeidsplasser og større sosial samhørighet. I denne sammenhengen omtales entreprenørskap som en grunnleggende ferdighet som skal vektlegges innenfor utdanning og livslang læring. Dette er etter hvert blitt kjent som «Lisboa-strategien» og fungerer fremdeles som en viktig markør på den politiske dagsorden. Strategien har videre legitimert mandatet til å fortsette bestrebelsene for å implementere entreprenørskap i skolen.

I rådets møte i Stockholm i 2001 ble det med utgangspunkt i Lisboastrategien presentert mål for utdannings- og opplæringssystemet knyttet til ulike spørsmål om hvordan denne strategien skulle fremmes. Møtet resulterte $\mathrm{i}$ at medlemslandenes utdanningsministre vedtok tre strategiske mål som det skulle satses på for det neste tiåret: a) å forbedre kvalitet og effektivitet $i$ utdanningssystemene $i \mathrm{EU}, \mathrm{b})$ å lette tilgang for alle til a erverve seg utdanning, og c) å åpne opp utdanningssystemer for verden utenfor.

Det ble tatt i bruk samme strategi i hele Norden - kanskje med unntak av Island - der man på tvers av flere departement utarbeidet strategiske planer hvor man ønsket å forankret opplæring innenfor entreprenørskap i utdanningssystemet. Det tverrdepartementale prinsippet er felles. I denne 
sammenhengen er kreativitet og innovasjon spesielt nevnt. Spesielt innenfor de praktisk-estetiske fagene er kreativitet og innovasjon sentrale begrep. I Island vektlegges også dette ved en mer helhetlig innovasjon av utdanningssystemet.

De første strategiske planene som ble utarbeidet i Norge, Danmark og Finland hadde relativt lik fokus, men den siste norske handlingsplanen (2009-2014) legger i sterkere grad vekt på entreprenørskap i høgre utdanning samtidig som prinsippene i den strategiske planen fra 2006-2008 føres videre i utdanningssystemet forøvrig. Nye strategiske planer avløste i 2009 de gamle planene i Norden. Sveriges nye strategi bringer forståelsen av entreprenørskap tydeligere i økonomisk retning. Definisjonen av entreprenørskap bringes også i den norske handlingsplanen (2009-2014) mer i retning av en økonomisk forståelse av entreprenørskap på samme måte som i Sverige.

I definisjonen av entreprenørskap, både i den norske og i den svenske strategiske planen fra 2009, er som nevnt økonomiske intensjoner påpekt tydelig, mens den finske planen i sterkere grad vektlegger opplæring til aktiv deltakelse i sosiopolitisk sammenheng. I Finland har den demokratiske dannelsen fătt en tydeligere plass i strategidokumentet enn i de øvrige nordiske landene. I den finske strategien vektlegges både elevaktiv læring, arbeidsplassforankret læring, kultur og samfunnsrelevant læring. Entreprenøriell læring forutsettes i større grad å skulle gi et helhetlig perspektiv på læring uansett nivå.

Dermed kan det oppstå et prinsipielt problem når man skal gi begrepet et pedagogisk meningsfylt innhold spesielt på lave alderstrinn. Entreprenørskap er et begrep barnehager og skoler ikke har vært fortrolig med. Det må fortolkes og fylles med et innhold der kreativitet og innovasjon nyttes som hjelpebegrep. Både kreativitet og innovasjon blir dermed sentrale delbegrep innenfor entreprenørskap. I Island har man ikke tatt i bruk begrepet entreprenørskap som betegnelse for erfaringslæring i barnehage og skole. Men begrepene innovasjon og kreativitet dekker i Island de samme lærings- og undervisningsprosessene som begrepet entreprenørskap dekker.

I Norge åpnet man gjennom læreplanrevisjonen «Kunnskapsløftet» (Lg06) for entreprenøriell læring innenfor fagene i grunnopplæringen. Den globale økonomiske krisen verden er inne i har bidratt til at den økonomiske forståelsen av begrepet entreprenørskap er blitt mer sentral. 


\subsection{Kreativitet, innovasjon og entreprenørskap}

I dette hovedpunktet tar vi med utgangspunkt i globaliseringens utfordringer opp forskningsspørsmålet:

- Hvordan er kreativitet, innovasjon og entreprenørskap omtalt i styringsdokumentene?

Å fostre kreativitet, innovasjon og entreprenørskap innebærer å fremme menneskelige egenskaper, holdninger og ressurser som skal sikre landenes bærekraft i framtida. De globale og nasjonale utfordringene består blant annet $\mathrm{i}$ å fremme skapende innovativ virksomhet, og å få frem dristige entreprenører. Kunnskap om å løse felles problemer ved å bygge gjensidig på hverandres bidrag kan utnyttes konstruktivt. Globalisering innebærer blant annet at man internasjonaliserer utdanningssystemene der danningsidealenes ultimale målsetting er å bidra til at den oppvoksende generasjon også blir verdensborgere. Det betyr at lokale, regionale og nasjonale problemstillinger og løsninger også må sees i en global kontekst. ${ }^{1}$

\subsubsection{Begrepsforståelse}

Begrepet entreprenørskap ble i utgangspunktet hentet fra den økonomiske sektor. Dermed blir det viktig å klargjøre hvordan man skal forstå begrepet entreprenørskap når dette benyttes - og fylles med til dels nytt innhold - i en pedagogisk kontekst. Når det gjelder definisjonsproblematikken bidrar OECD-rapporten (1989) med to definisjoner av entreprenørskap og dens utøvelse:

- En snever og tradisjonell tilnærming til entreprenørskap knyttes til «business» og viser til at unge på en eksperimentell basis lærer om å starte og å drive en bedrift.

- Den andre tilnærmingen benytter et entreprenørskapsbegrep som i hovedsak handler om kvaliteter og ferdigheter som gjør det mulig for enkeltpersoner innen organisasjoner og lokalsamfunn å handle fleksibelt og kreativt i møte med raske sosiale og økonomiske endringer. Fokus i denne tilnærmingen er derfor ikke primært, som i den smale tilnærmingen, å tilegne seg kunnskap om entreprenørskap, men den personlige utviklingen av de entreprenørielle egenskapene hos mennesket.

Rapporten belyser mulighetene for entreprenøriell læring innenfor den eksisterende skolens ramme. I denne sammenhengen forutsettes at pedagogisk entreprenørskap benyttes som begrep om å tilrettelegge for læring der målet er å utvikle de entrepreneurielle egenskapene hos individet.

\footnotetext{
${ }^{1}$ St.meld. nr. 14 (2008-2009) Internasjonalisering av utdanning
} 
Aktiviteter basert på den smale definisjonen har utviklet seg og fått en markant spredning innenfor utdanningssystemet, ikke minst på grunn av initiativ som er tatt fra aktører utenfor utdanningssystemet. Dette har gitt rom for aktører utenfor skolesystemet til å intervenere i utdanningssektoren. Lignende tendens finnes på politisk nivå der flere initiativ er tatt av andre departement enn medlemslandenes utdanningsdepartementer.

Begrepet entreprenørskap oppfattes i denne rapporten som en aktiv tilnærming og strategi der det skal investeres i hele samfunnet ved at entreprenørånden (entrepreneurial spirit) skal oppmuntres og gjennomsyre all opplæring.

\subsubsection{Arbeidsplasser og vekst}

EU-kommisjonen publiserte i 2003 «Green Paper - Entreprenørskap i Europa». Strategien er at entreprenørskap skal handle om å skape nye arbeidsplasser og initiere vekst, å fremme sosial og økonomisk utvikling i regioner og å integrere arbeidsledige og vanskeligstilte grupper $\mathrm{i}$ arbeidslivet. Dette perspektivet var også sentralt da de første strategiske planene utarbeides i Norden midt på 1990-tallet. Viktigheten av at man gjennom utdanning bidrar til å utvikle en entreprenøriell tankegang blant unge mennesker understrekes. Basert på erfaringene fra de siste fem årene med arbeid under Lisboa-strategien har Det europeiske råd besluttet at strategien skal reformeres. EUs innsats er tydelig og strømlinjeformet når det gjelder løsning av to oppgaver: 1) å skape bedre og flere jobber for å oppnå høyere og mer varig vekst og 2) bidra til å fremme en entreprenørskapskultur. Entreprenørskap blir sett på som «en viktig kompetanse for vekst, sysselsetting og personlig utvikling». Begrepet «ansvarlig entreprenørskap» tas i bruk, og det tidligere brukte begrepet entreprenørånd kommer tilbake og er nå definert slik:

\footnotetext{
Begrepet refererer til et individs evne til å gjøre ideer om til handling. Det inkluderer kreativitet, innovasjon og mot til å ta en viss risiko, evne til å lede og planlegge prosjekter for å oppnå mål som er fastsatt. Dette er en støtte for alle i hverdagen (både hjemme og i samfunnet) om å gjøre ansatte mer oppmerksomme på konteksten for deres arbeid, og mer tilbøyelig til å bruke mulighetene som er tilgjengelige for dem. Det er et grunnlag for mer spesifikk kunnskap og gründerkompetanse for å etablere sosial eller kommersiell aktivitet.
}

Det reviderte Lisboa-programmet støtter arbeidet med å utvikle dynamiske strategier for entreprenørskap i utdannelse gjennom en rekke anbefalinger: 1) internasjonalt og tverrdepartementalt samarbeid 2) pedagogiske mål og aktiviteter for entreprenørskap samt 3) lærerutdanning innenfor entreprenørskap. I tillegg gås det inn for at partnerskap mellom utdanning og lokalsamfunn oppfordres. Eksterne aktører som tilrettelegger for at elevene kan prøve å drive minibedrifter bør få systematiske støtte. Europakommisjonen utpekte 2009 til det europeiske året for kreativitet og innovasjon. Ambassadører ble utnevnt, og i et manifest ble det prokla- 
mert at spesielt skoler og universitet skal være sentra for kreativ tenkning og «entreprenøriell læring».

Entreprenørskap, innovasjon og kreativitet i pedagogiske sammenheng er, som vist ovenfor, markert på overnasjonalt nivå i en rekke rapporter, program og avtaler. Disse angir noe av bakgrunnen for hvordan entreprenørskap er utredet og planlagt implementert i skoleverket i de nordiske landene.

\subsection{Pedagogisk entreprenørskap}

I Nordisk ministerråd sin utlysning av denne studien er neste forskningsspørsmål formulert slik:

- Hvordan er kreativitet, innovasjon og entreprenørskap iverksatt i opplæringen/undervisningen (barnehage/førskole, grunnskole, videregående opplæring (ungdomsutbildningen), herunder både studieforberedende og yrkesforberedende program samt voksenopplæringen og i lærerutdanningen)?

En entreprenør skulle opprinnelig bidra til å avdekke ufullkommenhet eller mangler i markedet (Schumpeter 1983, Kirzner 2008, Gartner 1985) for å kunne generere innovasjoner i markedet ved å utnytte mulighetene man kunne se som følge av den observerte ufullkommenhet, ved for eksempel å etablere ny virksomhet. Entreprenørskap består ut ifra en slik forståelse av tre elementer:

- avdekke imperfeksjon (mangler eller ufullstendighet)

- generere innovasjoner som følge av avdekkingen

- skape ny virksomhet, eksempelvis nye bedrifter

Denne måten å forstå entreprenørskap på er sentral innenfor entreprenørskapsforskning med utgangspunkt i økonomiske motiver.

Men begrepet entreprenørskap har også fått en sentral plass innenfor utdanning og opplæring. Entreprenørskap oppfattes i en slik kontekst som et danningsmål representert ved ulike personlige egenskaper man skal fostre i opplæringsprosessene - fra banehagenivå til selvstendig yrkesutøvelse. Entreprenøriell dannelse er ved dette definert som en sentral oppgave for utdanningssystemet. Denne måten å forstå entreprenørskap på innebærer at å finne fram til et hensiktsmessig innhold og relevante arbeidsmåter innenfor de langsiktige læringsprosessene som realiseres i ulike utdanningsinstitusjoner. Disse prosessene skal på lang sikt føre fram til at barn og unge tilegner seg en entreprenøriell tenkemåte (mindset) slik at de kan realiserer sitt eget livsprosjekt på en konstruktiv måte gjennom hele livet. Pedagogisk entreprenørskap dreier seg om å tilrettelegge læ- 
ringssituasjoner som fremmer de personlige egenskapene (verdier, kunnskaper, holdninger og ferdigheter) som kjennetegner entreprenører. Gjennom pedagogisk entreprenørskap skal det skapes mennesker med stor evne til å omstille seg og fremragende entreprenører som skal bidra til å utforme framtida. Etableringen av vitenskapsområdet pedagogisk entreprenørskap har derfor utvikling av de menneskelige ressurser som sin primære funksjon.

Pedagogisk entreprenørskap omtales ofte ved å benytte begrepene innovasjon og kreativitet som underordnete begrep. Innenfor det norske utdanningssystemet assosieres entreprenørskap vanligvis med bedriftsetablering. På de øverste trinnene i grunnopplæringen og innenfor voksenopplæring er dette naturlig, men på det laveste alderstrinnet må det være grunnleggende kreativ og skapende virksomhet som skal bidra til å fremme entreprenørielle egenskaper hos barn. Kunnskap om markedsmessige forhold og bedriftsetablering har imidlertid en naturlig plass på høyere alderstrinn.

Entreprenørskap innenfor utdanning og opplæring ble satt på dagsorden i 1996 i forbindelse med NMRs konferansen i Jyveskylä. Dette fikk konsekvenser for utviklingen av implementeringsstrategier i hele Norden. Strategiene som ble valgt i de nordiske landene var i hovedsak samsvarende. Utvikling av strategiske planer med sterk påtrykk fra næringslivet var felles. Forventningene til opplæringssystemene var tydelige når det gjaldt å bidra til å stimulere interessen for å skape arbeid. Dette gjelder også Island selv om dette landet ikke tok i bruk begrepet entreprenørskap. Men i Island la man desto større vekt på innovative tiltak som alltid har vært et kjennetegn på entreprenørskap. Strategiske planer som ikke følges opp med aktuelle prosjekter og økonomisk stimulering blir i liten grad lagt merke til i opplæringssystemene. Det er først med referanse til de nyeste handlingsplanene økonomiske initieringsmidler har vært tildelt $i$ et omfang som innebærer at entreprenøriell aktivitet foregår (2009). Våre studier av entreprenørielle tiltak på de forskjellige nivåene i utdanningssystemene viser at det først og fremst er i grunnskole- og ungdomsutdanningen (16-19/20 år) entreprenørskapstanken har fått en betydelig grobunn.

\subsubsection{Nivå-perspektivet}

Begrepet entreprenørskap var «en fremmed fugl» i skoleverket da det ble tatt i bruk i forbindelse med skoleutviklingstiltak midt i 1990-årene. Og etter som begrepet i særlig grad ble begrunnet med at skolens bidrag skulle være å redusere arbeidsledighet og etablere bedrifter, bidro det heller ikke til å skape mening for opplæringen spesielt av barn på lave alderstrinn. Dette var ikke selvfølgelig tankegods for den etablerte pedagogisk virksomhet i grunnskolen, og det var heller ikke lett å se de langsiktige effektene av slik satsing. 
I barnehagen gjennomføres det imidlertid tiltak som begrunnes med satsing på entreprenørskap. Eksempler fra den norske rapporten dokumenterer dette. Når fokus rettes mot pedagogisk entreprenørskap, og dette betyr at man satser på læringsformer som på lang sikt skal fremme entreprenørielle egenskaper, får begrepet entreprenørskap en annen betydning enn når markedselementet og bedriftsetablering utgjør definisjonen av begrepet. I barnehagen er det også viktig å være oppmerksom på at utøvelse av pedagogisk entreprenørskap i særlig grad gjelder læring i institusjonens voksne miljø.

I grunnskolen - spesielt på ungdomstrinnet - har det over en lengre periode vært anvendt elevbedrifter. Ungt entreprenørskap har også på dette nivået vært en aktiv pådriver og har stimulert utviklingen $i$ alle de nordiske landene. Realistisk tilrettelagt, og med god veiledning, synes elevbedriftsmetoden utvilsomt å ha potensial som allsidig læringsfremmende, motiverende, aktiviserende og skapende arbeidsform. For mange elever har bruk av elevbedrifter gitt skolens innhold en ny mening for dem.

I videregående skole (gymnas/ungdomsutdanningen) gjelder mye av det samme som er nevnt ovenfor angående grunnskolen. Men på dette alderstrinnet er det naturligere å se entreprenøriell læring sterkere relatert til arbeid, bedriftsetablering og tilrettelegging av ny virksomhet. Opplæringen på dette nivå kan derfor inneholde flere elementer som inngår i den klassiske forståelsen av entreprenørskap (Schumpeter, Kirzner og Gartner).

Innenfor voksenopplaringen er det bedriftsorienterte perspektivet på entreprenørskap naturlig nok framtredende. Opplæring vil i sterkere grad være instrumentell enn dannende. Det er på dette nivået kompetanseutvikling på kortere sikt som gjelder. Et langsiktig forstringsperspektiv er ikke så aktuelt. Pedagogisk påvirkning vil i større grad angå læring av kunnskaper og ferdigheter relatert til det vi har kalt en klassisk forståelse av entreprenørskap. Dette muliggjør også at formidling av kompetansekurs innenfor entreprenørskap kan foregå både i en arbeidsmarkedskontekst og innenfor det ordinære utdanningssystemet.

Innenfor universitet og høgskoler er det etablert utdanning innenfor entreprenørskap spesielt ved handelshøgskoler og økonomiske institutt. Ved lærerutdanningsinstitusjonene er det også etablert slik utdanning innenfor entreprenørskap flere steder i Norden. Profilen på denne utdanningen er noe ulik, men utdanningstiltakene er under oppbygging og endres i takt med kunnskapsutviklingen i barnehage, grunnopplæring m.v. Nyere handlingsplaner spesielt i Norge og Sverige (2009) fokuserer på behovet for å satse bredt på entreprenørskap innenfor høgre utdanning, herunder lærerutdanningen.

\subsubsection{Fra nærings- til læeringsfokus}

Våre hovedfunn viser at anvendelsen av begrepet entreprenørskap innenfor utdanning og opplæring har endret seg i løpet av de 20 årene begrepet 
har vært benyttet i en pedagogisk kontekst. En bedriftsorientert og næringsmessig tilnærming er supplert med en pedagogisk, læringsmessig tilnærming. Dette er naturlig etter som begrepet entreprenørskap også er tatt i bruk på lave alderstrinn i skolen og i barnehagen. Dermed blir også entreprenøriell dannelse - eller fostring - en sentral langsiktig målsetting og medfører at kreativitet og skapende virksomhet får en betydningsfull plass i opplæringen. Når entreprenøriell læring fokuserer på aktive læringsformer, relasjonen til lokalsamfunnets institusjoner og samspill med bedrifter og kulturliv så betyr dette å videreføre lange tradisjoner i utvikling av en samfunnsaktiv skole spesielt i distriktene. På kort sikt er det urealistisk å forvente at grunnopplæringen kan bidra med betydningsfull effekt i omstillingsprosesser i samfunnet ved å fokusere en entreprenørskapsforståelse som primært dreier seg om utprøving av elev- og ungdomsbedrifter. Men på lang sikt kan et slikt læringsfokus bidra i danningsprosessen og påvirke elevenes holdninger til arbeid og deltakelse i utvikling av virksomheter.

\subsubsection{Behov for skoleutvikling}

Pedagogisk entreprenørskap innebærer også at læreres og lederes kompetanse utfordres. Dette har konsekvenser for læreres grunn- og videreutdanning. Innovasjonspotensialet ved utviklingsorienterte skoler er avhengig av skolens menneskelige og materielle ressurser og dermed også skolens endringskultur. Skoleutviklingsperspektivet blir derfor sentralt. Pedagogisk entreprenørskap handler i særlig grad om ledelse, ledelsens rolle og skoleutvikling.

\section{Entreprenørskapsundervisningens innhold}

Felles perspektiv i nordiske skoler:

Læring gjennom egne erfaringer og egen aktivitet, individuelt læringsansvar, arbeidsmåtene, elevbedrifter, «europeisk læreplan» i entreprenørskap, nyskaping, dramatisering av tidsreiser i barnehagen, nærsamfunnet brukes, å gjøre, fri skaping, kafédrift, å drive «butikk», gammel og ny teknikk, kulturarrangement, kreativitet, kreative personer og virksomheter, samarbeid med bedrifter, foretak, internasjonale kontakter, serviceoppdrag, lokal utvikling, regional utvikling, samspill mellom skole og arbeidsliv, fokus på skolens indre pedagogiske arbeid (pedagogisk entreprenørskap) ikke ytre bedrifter med pengeinnsamling og profitt som mål! Tverrfaglighet, tverrvitenskapelig, aktiv læring, oppmykede rammer osv.

Særtrekk ved satsingen basert på de nyeste strategiske planene (2009-2015)

Danmark: Entreprenørskap skal på skjemaet. En ny koordineringsinstans «Fonden for entreprenørskap» - har fått en sentral rolle i utviklingen av pedagogisk entreprenørskap. Verdiskaping gjennom viten understrekes som mål. Entreprenørskapssentre ved universitetene. Ny etisk kompetanse, solidaritet. Utvikle talentene.

Finland: Begrunnes med barnesentrert og helhetspreget pedagogikk som også har fokus på medborgerskapsopplæring.

Island: Innovasjonsbegrepet erstatter entreprenørskap. Fornyingsfokus. Barnehagen er en del av skolesystemet.

Norge: Fokus på universitet og høgskole + forankring i læreplan (Lg06) og i veiledninger til fagplanene. Lokale initiativ for entreprenørskap i barnehagene. Ungt entreprenørskap en sentral rolle.

Sverige: Sterkere økonomisk stimuleringstiltak enn før. Økonomisk styring via prosjektstøtte. 
Felles problem: Lærerutdanningen har hengt etter i utviklingen av kompetanse innenfor dette feltet. Det har vært utført lite forskningsmessig oppfølging og didaktisk tilpasning av fagene. Og det har til dels vært en feilaktig oppfatning og idealisering av elevbedrifter - som etter manges oppfatter har preg av å være pengeinnsamlinger. Entreprenørskap handler ikke primært om å drive «butikk», men å benytte bedriftsmetodens potensial for å gi elevene ny motivasjon og positiv læringseffekt. Begrepet entreprenørskap er som vist ovenfor ikke like godt implementert og akseptert i barnehage og i grunnskole. Men pedagogisk entreprenørskap skal bidra både som personlighetsutviklende og sosialt utviklende prinsipp og gjennomsyre undervisningen.

En måte å belyse hva man mener med pedagogisk entreprenørskap er å vise forskjellen på tradisjonell og entreprenøriell pedagogikk. Hensikten med entreprenørskap i skolen er å videreutvikle og å berike elevenes erfaringer. Men begrepet entreprenørskap har også sammenheng med økonomisk utvikling på lang sikt. Tradisjonell kunnskapsformidling, ensidig formidling av informasjon som var tilpasset en foreldet samfunnsform og en foreldet økonomi - i motsetning til sammensatte behov som foreligger i et demokratisk samfunn basert på en fleksibel markedsøkonomi. I et slikt samfunn innhentes informasjonen når det er bruk for den, men dette stiller andre krav til brukeren enn i tradisjonssamfunnet. Det er viktig at pedagogisk entreprenørskap både retter fokus mot politiske, strategiske, metodiske og didaktiske begrunnelser for forandringsvirksomheten som pågår i entreprenørskapets navn.

\subsection{Politiske initiativ på nasjonalt nivå}

Dette emnet er belyst ut ifra problemstillingen:

- Hvilke initiativ og satsinger er iverksatt for å fremme kreativitet, innovasjon og entreprenørskap i opplæringen/undervisningen?

I utredningene fra hvert av de nordiske landene vises hvordan begrepet entreprenørskap i løpet av de siste femten årene har vært satt på den politiske dagsorden og hvordan dette er knyttet til utdanning. En like klar markering av begrepene kreativitet og innovasjon finnes ikke, men ofte refereres det til disse begrepene som aspekt ved det overordnete begrepet «entreprenørskap». Men kreativitet og innovasjon har over lang tid vært benyttet i pedagogisk sammenheng og er derfor kjente begrep. Rapportene fra de nordiske landene viser at internasjonale initiativ (Det europeiske råd, Nordisk ministerråd, Lisboa-strategien, OECD m.fl.) følges opp og har hatt betydelig styringseffekt.

Konseptet med valg av nye strategier omfatter utvikling av nye ideer og å omsette disse ideene til verdiskapning i bedrifter, i offentlig og fri- 
villig sektor. ${ }^{2}$ Det som skaper en god entreprenør: evnen til å løse problemer, tenke nytt, planlegge arbeidet, ta ansvar og samarbeide med andre, er egenskaper studenter på ulike nivå må utvikle for å takle sine studier og for å bli vellykket i voksen alder. På universitetsnivå vil entreprenørskapsutdanning handle om både teoretiske og praktiske studier av hele prosessen med å undersøke at ideenes kommersielle levedyktighet for å etablere en bedrift i markedet - er realistisk. Internasjonale perspektiv begrunner tiltak som etter hvert er realisert på regionalt og lokalt nivå. Den økte betydningen som ble tillagt entreprenørskap i skolen har stimulert framveksten av mange regionale tiltak. I flere norske fylker med egne vekst- og utviklingsprogram ble utviklingstiltak støttet for å styrke prosjekt som har blitt vedtatt. I tillegg har mange kommuner formulert mål for økt entreprenørskap i de kommunale skoleplanene.

\subsubsection{Kreativitet og innovasjon}

Kreativitet er en kombinasjon av kognitive prosesser, personlige egenskaper og sammensatte virkemidler. Kreativitet dreier seg om hvordan man kan identifisere ideer, hvordan man ser og oppfatter problemer i omgivelsene og hvordan man håndterer en mulig innovativ løsning. ${ }^{3}$

Innovasjon kan defineres som en ny eller fremtidsrettet praktisk anvendelse av et produkt, en prosess eller en tjeneste basert på målrettet samarbeid som imøtekommer brukernes behov for å forbedre sine liv (Lindfors 2009). Kreative ideer er helt avgjørende for utvikling av problembaserte løsninger og aktiviteter. Beslutningstakere rundt om i verden vektlegger også at innovasjon er avgjørende for utviklingen av global velferd.

I forhold til entreprenøriell læring kan vi tale om entreprenørskapsutdanning der entreprenørskap defineres som et individs evne til å transformere ideer til handling. Dette inkluderer kreativitet, innovasjon og å ta risiko, samt evnen til å planlegge og å styre prosesser som må gjennomføres for å oppnå målene. Entreprenørskap betyr også å vise engasjement og uavhengighet, og å initiere nyskapende prosesser i læringsmiljøet. Dette er også et bidrag i en moderne form for organisasjonsutvikling som startet på midten av 1990-tallet. «Entreprenørskap» og «entreprenøriell læring» begynte å bli generelle konsepter i denne perioden.

\subsubsection{Entreprenørskapsutdanning}

I dette punktet refereres mest til erfaringer fra Finland, men innholdet er representativt for Norden som helhet. Med bakgrunn i snart 20 års virksomhet er strategien for å fremme entreprenørskap i utdanningen i Fin-

2 Den svenske og den norske regjeringen vedtok våren 2009 nasjonale strategier for «Entreprenørskap i utdanning».

3 Defineringen av kreativitet, innovasjon og entreprenørskap referer til den finske rapporten, kp 2. 
land sammenfattet i ni områder: regjeringens program og retningslinjer, statlige normer og informasjonsbehandling, lærernes grunnutdanning og videreutdanning, utvikling av entreprenørenes pedagogiske ferdigheter, forskning, utvikling og evaluering. Innovativ satsing på disse områdene følger i hovedsak forhold som er sterkt vektlagt på europeisk nivå.

Det konservative samlingspartiet framhever behovet for å satse på livslang læring og kreativitet. Etablering av «foretak» er kun omtalt i forbindelse med økonomisk og «ytre» entreprenørskap. Internt entreprenørskap utvikling av «human resources» - framheves spesielt av senterpartiet som vektlegger fostringen av foretaksomhet, mens sosialdemokratene vektlegger kreativitet i sammenheng med kunst, kultur og velvære. Temaet innovasjon knyttes i sterkere grad til høyskoleutdanning (SDP 2008).

Regjeringens program for 2007-2011 framhever satsingsområder der både kreativitet, innovasjon og «föratagsamhetsfostran» trekkes inn i utdannings- og næringspolitikken (Government Programme 2007-2011). I tillegg har regjeringen i Finland for 2007-2011 sin egen innovasjonspolitikk. Regjeringen legger vekt på ekstern virksomhet i samfunnet ved å styrke innovasjonskapasiteten i økonomien gjennom strategiske investeringer i utvalgte kunnskapsmål, ved å støtte faglig utvikling og å forbedre vilkårene for fremveksten av nye, gjerne mer risikable foretak.

For å nå målene har regjeringen forpliktet seg til å fremme kreativitet, samt å ta vare på ulike former for talent og bidra til innovasjon tidlig i utdanningsløpet. Den kreative økonomien skal styrkes nasjonalt og har fått økt betydning noe som innebærer å stimulere utvikling av entreprenørskapskulturen.

Det finske undervisningsministeriets retningslinjer omtaler også konkrete mål og innhold. Det finske undervisningsministeriet har som mål å styrke enkeltpersoners entreprenørskapsånd og gi bedriftene mulighet til å fremme attraktive karrierer. Arbeidet med å styrke entreprenørskap dekker hele utdanningssystemet. Man vil støtte etablering av selvstendig virksomhet og fremme ansvar for, og evne til å mestre eget liv. Områder for satsing og intervensjon ved å opprette læringsmiljøer som gjør at studentene tar utdanning som bygger opp om bedriftens utdanning, lærerutdanning, læreres kontakt med arbeidslivet, arbeidslivspraksis for lærere, studieguider, ta i bruk gründere i skolens arbeid og ved å produsere materialer.

Målet er i Finland - som i Norden for øvrig - at mer entreprenørskap bør springe ut av både yrkesfaglig og høyere utdanning. En gründerkultur og hensiktsmessig driftsmodellen kan best utvikles i samarbeid med samfunnet og i samsvar med målene for entreprenørskapsutdanningen som etableres for hvert utdanningsnivå (Ministry of Education 2009). 


\subsection{Entreprenørskapets rolle i utdanningssystemet}

I dette punktet søker vi å avklare hva slags rolle entreprenørskapssatsingen i utdanningssystemene bør ha og hva slags hovedinnhold begrepet «pedagogisk entreprenørskap» bør formidle. Vi velger også her å nytte globale perspektiv i våre vurderinger for å bidra til å øke bevisstheten om nødvendigheten av å trekke globale perspektiv inn når nasjonale, regionale og lokale forhold omtales. Dette perspektivet trekkes inn i analyser og vurderinger av materiale som finnes i den enkelte skoles virksomhetsplaner. Her finnes det materiale som vil vise om skolen implementerer globale perspektiv i utviklingen av virksomhetsplan. Ledelsen står i denne sammenheng overfor store utfordringer.

\subsubsection{Globaliseringsdiskurser og kunnskapsbasert økonomi ${ }^{4}$}

I politiske styringsdokumenter i Danmark er det en formulert forutsetning at en kunnskapsbasert økonomi har gitt utdannelsessystemet en ny rolle i utvikling, formidling og forvaltning av kunnskap. Dette plasserer utdanning og læring i det politiske sentrum når kunnskap oversettes til utøvende praksis, og har høynet interessen for fenomener som utvikling av «kreativitet» og «entreprenørskap» som grunnlag for innovasjoner, oppfinnelser, aktivitetsdominert pedagogikk og samspill med næringslivet. På bestemte områder er læring et rent «arkitektonisk» uttrykk for å støtte utviklingen av ideene for på lengre sikt å kunne skape innovasjon, utvikle talent og idégenerering (Robertson, 2009). Utdanning, kunnskap og innovasjon oppfattes som avgjørende for å utvikle en globalt konkurransedyktig og kunnskapsbasert økonomi. Kunnskap er avgjørende for utvikling av en økonomi basert på følgende pilarer i kunnskapssamfunnet: innovasjon, ny teknologi, human kapital og enteprenøriell leringsdynamikk.

Verdensbanken har spilt en avgjørende rolle i utvikling av strategien ved å fokusere på:

- Et økonomisk og institusjonelt regime som må skape incentiver for effektiv bruk av både eksisterende og ny kunnskap og for å få entreprenørskap til å blomstre

- Utdannede dyktige mennesker som er flinke til å skape, bruke og dele kunnskap

- Etablere et effektivt innovasjonssystem av bedrifter, forskningssentre, universiteter, idé - smier, konsulenter og andre organisasjoner som kan passe inn i en økende mengde global kunnskap, tilpasse den til lokale behov og bidra til å skape ny teknologi

- Informasjons- og kommunikasjonsteknologi (IKT) for å støtte effektiv kommunikasjon, deling og oppretting av informasjon

\footnotetext{
${ }^{4}$ Dette punktet referer spesielt til den danske rapporten, kp 1.
} 
EU-kommisjonen og Verdensbanken bruker lignende kriterier for å måle kunnskap og innovasjonsaktivitet basert på Lisboa-erklæringens intensjoner og ser det som en oppgave å gjøre EU til den mest konkurransedyktige kunnskapsøkonomien i verden. Dette betyr at også tjenesteytende sektor, utdanning, helse, finans og transport tilrettelegges for å initiere konkurranse. Utdanning blir sett på som en tjenestesektor som kan bidra direkte til økonomisk utvikling. Innovasjon er forbundet med bruk av ny og avansert teknologi og andre innovasjonsprosesser beskrevet som «myke» og viktige i disse sektorene for å gi bedre tjenester og takle framtidige utfordringer.

På denne bakgrunn er det rimelig å anta at man må intensivere fornying av offentlig sektor for å sikre et avgjørende innovasjonspotensial. Hvis vi bare måler innovasjonens verdi i form av produksjon, spinn off i selskaper og patenter kan det føre til forskning som fokuserer for ensidige på innovasjonstiltak. Globale spørsmål som befolkningsvekst, klimaendringer, mangel på ressurser og den økonomiske krisen konstituerer en ny agenda som tilsier behov for utvikling av «solidaritet» og etisk innovativ kompetanse basert på et globalt perspektiv som kanskje ikke samsvarer med ren økonomisk profitt. Disse utfordringene kreves det fantasi, kunnskap, analytisk, kritisk og kreativ problemløsning for å håndtere.

\subsubsection{Globaliseringsstrategi i politikken}

I lys av globaliseringstrendene er det interessant å observere hvordan diskurser om innovasjon vises i utdanningspolitikken. I Danmark gav Globaliseringsrådet i 2006 ut en strategi «følelse av sikkerhet, velstand og fornyelse», som la stor vekt på kreativitet, innovasjon og entreprenørskap som en faktor for fortsatt vekst og velstand. Innovasjonsdiskursen i skolen bruker beslektede begreper - kreativitet og entreprenørskap - og er definert som klart positiv. Det brukes fraser om å ha «verdens beste skole», «utdanning i verdensklasse» osv. (Globalization Council).

I 2009 lanserte departementet for vitenskap, teknologi og innovasjonsstrategi utdanning i entreprenørskap. Dette betyr at utdanning i entreprenørskap skal bidra til å skape flere nye bedrifter med vekstpotensial og flere gründere. Den fremtidige konkurransekraften vil styrkes av det faktum at utdannelsessystemet stimulerer unge menneskers evne til å tenke nytt, se muligheter og omsette ideer til aktivitet og verdier. Men regjeringens siste plan for arbeidet er ikke først og fremst preget av kreativitet og innovasjonsutvikling, men svært mye satses på tradisjonelle skolefag og på den offentlige skolens faglige grunnlag og kan derfor betegnes som en motdiskurs

I Island anvendes gjerne begrepene «innovative tiltak og iverksetterundervisning» i grunnskolen slik at dette i hovedsak dekker begrepet pedagogisk entreprenørskap. Det sies i rapporten fra Island at: 
Det er først med udformningen af grundskoleloven af 2008 (Alpingi Íslands 2008 B), at det eksplicit i loven om grundskolen udtrykkes en satsning på innovation (isl. nýsköpun) og iværksætterundervisning (isl. frumkvöðlanám)... og «Når de to begreber innovation og iværksætterundervisning overhovedet finder en plads i grundskoleloven, så er det affødt af, at man siden slutningen af 1990erne har arbejdet med innovation og iværksætterundervisning på flere forskellige fronter og niveauer i grundskolen».

Det må også nevnes at innføring av faget «Innovasjon og praktisk bruk av viten» bygger på idéutvikling, problemløsning og å finne fram til nye resultater gjerne ved hjelp av informasjonsteknologi. Visjonen i skolen $\mathrm{i}$ Norden er at elever og studenter skal få innføring i entreprenøriell læring og kreativ tenkning, utvikle kunnskap om entreprenørskap og å handle entreprenørielt. Dette forutsetter en innovativ pedagogikk og innovative undervisningsmetoder, og det må også fokuseres på en didaktikk som styrker den innovative bruken profesjonelt. For entreprenørskap i undervisningen finner sted når en skole deltar aktivt i utviklingen av det omkringliggende samfunnet og skaper muligheter slik at elevenes aktiviteter både på kort og lang sikt skaper verdi i form av kunnskap, produkter og tjenesteytelser etter behov. Dette omtaler vi også som pedagogiske entreprenørskap, kreativ og innovativ virksomhet.

\subsubsection{Lærerutdanningen}

Lærerutdanningen har en sentral plass i kompetanseutviklingen både i den grunnleggende utdanningen av lærere og gjennom etter- og videreutdanning. I studiene vi har utført avtegnes det ikke et entydig bilde av hvordan kompetanseutviklingen foregår. Flere aktører interesserer seg spesielt for læreres etterutdanning. Nedenfor nevnes kun noen tiltak som er spesielle i det enkelte land. ${ }^{5}$

Danmark: I lærerutdanningen forutsettes at utdanningen skal formidle entreprenørielle undervisnings- og læringsformer innenfor alle fag. Kompetansen spres via nyutdannede lærere. Fonden for entreprenørskap har fătt en rolle både i forskning, kunnskapsbygging, nettverksbygging og kompetansespredning. Profesjonshøgskolenes tilbud vektlegger gjerne det innovative og kreative, men ofte uten at begrepet entreprenørskap benyttes. Profillcererutdanningen som gjennomføres ved profesjonshøgskolen Metropol (København) er spesielt interessant med valgtilbud, eksempelvis med sammensettingen av natur og teknikk, estetikk og innovasjon (mfl). Pedagogutdanningen i Aalborg har også en tydelig innovasjonsprofil. Det samme gjelder tiltak som utvikles ved Vitenssenteret ved UCN. Det kan gis hjelp og etableringsstøtte blant annet med referanse til «Den kreative plattformen».

Finland: Temaet foretaksomhetsfostring tillegges betydelig vekt både innenfor lærerutdanning, yrkesutdanninger for øvrig samt innenfor uni-

\footnotetext{
${ }^{5}$ Det gis her bare noen oppsummerende formuleringer. Det vises til utfyllende beskrivelser i kp 1.
} 
versitet og høgskoleutdanning. Målsettingen er å spre etableringskompetanse. Utdanningstiltakene har sterkt fokus på «ytre entreprenørskap», kunnskap om etablering av ny virksomhet. Innenfor utdanningssystemet er det imidlertid kompetanse innenfor «indre entreprenørskap» - den entreprenørielle læring og undervisning - som må prioriteres. Her er det behov for kompetanseutvikling både på det pedagogisk-/didaktiske feltet og profileringen av kreativitet og innovasjon som dynamiske faktorer i kompetanseutviklingen.

Island: Vi har nevnt at begrepet entreprenørskap ikke har noen sentral plass i den pedagogiske terminologi Island. Dette gjelder også lærerutdanningen. Begrepene kreativitet og innovasjon er imidlertid viktige og brukes mye. Disse begrepene har vært i bruk innenfor lærerutdanningen siden 1994. Innovasjonsvirksomheten har i særlig grad vært koblet til innføringen av informasjonsteknologien. Kreativitet og innovasjon vektlegges som integrert innhold/arbeidsmåter innenfor alle fag i lærerutdanningen. Dette gjelder også kreativ bruk av fleksible læringsformer i lærerutdanning og kompetanseutvikling generelt. Islands pedagogiske universitet ivaretar kompetanseutvikling med vekt på kreativitet og innovasjon.

Norge: Kompetanseutviklingen innenfor entreprenørskap har vært vektlagt svært ulikt ved lærerutdanningsinstitusjonene i Norge. Entreprenørskap gis som utdanningstilbud ved flere økonomiske og tekniske institutt ved universitet og høgskoler. I den nye strategiske planen «Entreprenørskap i Utdanning 2009-2014» forutsettes det at pedagogisk entreprenørskap skal inngå i alle fag i lærerutdanningen. Grunnopplæringens arbeidsmåter skal gjennomsyres av elevaktive læringsformer. Lærerutdanningsinstitusjonene tilbyr noen mindre etterutdanningskurs, men formalisert videreutdanning er tilrettelagt gjerne som kurs med et omfang på 30-60 ECTS. Ved Høgskolen i Bodø har slike kurs vært gjennomført innenfor entreprenørskap generelt, pedagogisk entreprenørskap, inkubasjon - lederopplæring m.m. Ungt Entreprenørskap har også fått en rolle gjennom statlige bevilgninger ved å utvikle og gjennomføre kortere impulskurs som tilbys skolene som etterutdanning. Med referanse til den siste strategiske planen er det grunn til å forvente opptrapping innenfor kompetanse-/kunnskapsbyggingsfeltet.

Sverige: Lærerutdanningens kvalitet vurderes som en forutsetning for kompetanseutvikling innenfor utdanningssystemet. Også den svenske lærerutdanningen skal fornyes. I proposisjonen «Best i klassen, en ny lararutbildning, 2009-10: 89», framheves utdanningens betydning og at dette dreier seg om innovasjon innenfor skolen, og innovasjon av skolen. Men begrepet entreprenørskap anvendes ikke i denne proposisjonen. Emnet entreprenørskap er likevel tatt inn som kompetansegivende studietiltak i lærerutdanningen flere steder: entreprenørskapets didaktikk, entreprenørskap og skole, entreprenøriell læring, foretaksom læring, etc. Lærerstudenter har sjelden tilgang til slike kurs og antallet lærere som følger slike kurs er ikke høyt. Forskning på dette feltet foregår i begrenset om- 
fang ved flere universitet (Luleå, Umeå, Midtuniversitetet Hernösand, Vāxjö, og Mālardalens universitet). Ved Umeå universitet finnes et forskersentrum for entreprenøriell pedagogikk og læring. Her er det de siste årene publisert avhandlinger og studier på dette feltet.

\subsection{Aktører utenfor utdanningssystemet}

Noen eksterne interessenter bidrar til å fremme entreprenørskap innenfor utdanningssystemet i alle nordiske land. Det vises til kapitlene for det enkelte land. ${ }^{6}$ Her nevnes kun noen aktuelle institusjoner, organisasjoner og tiltak:

- Hvilke aktører fra næringslivet, partene i arbeidslivet engasjerer seg i dette arbeidet?

I det danske utdanningssystemet er det naturlig å nevne «Fonden for entreprenørskap» som koordinerende instans for å ivareta kompetanseoppbyggingen innenfor pedagogisk entreprenørskap. Dette er en institusjon som fungerer som et nasjonalt senter i skjæringsfeltet mellom å være intern og ekstern aktør. Det er viktig at denne type aktør følges opp med vitenskapelig evaluering av organisasjonsform og funksjon. Når tilstrekkelig erfaring er vunnet må det være interessant å vurdere en mulig overføring av modellen til de andre nordiske landene. I Danmark er også «non-profit» organisasjonen Young Enterprise (YE) aktiv. Pionerutdanningen, pionerspiren og aktiviteter med Lego og «First Lego League» som aktør må også nevnes. Det samme gjelder utviklingen av en verktøykasse og guide for elever og lærere om å lære innovasjon i skolen (ABC Innovation og Innovationsrådet). Her har et konsortsium av «tunge» eksterne aktører bidratt i utviklingen.

I Finland finner vi eksempler på at eksterne aktører har bidratt med materiellutvikling. Her nevnes Klubbcentralen som produserer materiell for foretaksomhetsoppfostring i samarbeid med foretaksorganisasjoner. «Titta i kaleidoskopet» produserer idègivende materiell for lærere på de øverste trinnene i grunnopplæringen. I Finland vektlegges også bruk av virtuelle plattformer og spredning via nettsteder. YVI er under konstruksjon og nevnes som samarbeidspartner for yrkesutdanning, gymnas, allmenn utdanning, arbeidsliv, organisasjoner og kommuner. Også i Finland er «Ung Føretagsamhet» aktiv som kursaktør og materiellutvikler. Tevlinger isenesatt av eksterne aktører benyttes også for å inspirere i fostringen til entreprenørskap. Andre tiltak inspirerer til en foretaksom livsstil og yter bidrag for å initiere fremtidsrettet tenkning.

\footnotetext{
${ }^{6}$ Sentrale aktører er omtalt under pkt. 1.6 i det danske bidraget, i pkt. 4 i det finske bidraget, pkt. 3.4.2.3 i det islandske, pkt. 4.4. 8 i det norske og i pkt. 5.6.2 i det svenske bidraget
} 
Det er noe vanskeligere å identifisere eksterne aktører innenfor dette feltet i Island. Dette henger sammen med måten begrepene nyttes på. Men det er mulig å identifisere innovasjoner og innovative tiltak som paralleller til eksterne aktører slik disse omtales i rapportene for øvrig. Det vises spesielt til arbeidet som har foregått med sikte på implementering av IKT i undervisningen. Flere firma - eksterne aktører - tilbyr digitale læringsressurser basert på kommersielt grunnlag. Selskapet rasmus.is nevnes spesielt fordi det produserer materiale innenfor matematikk og naturvitenskapelige fag på flere språk (norsk, svensk og dansk) mot en årsavgift på 700 DKK. Det finnes også nettsteder innenfor fremmedspråk og islandsk som andrespråk (Katla-prosjektet).

Også i Norge er Ungt Entreprenørskap (UE) en relativt stor og aktiv ekstern aktør på dette området. Denne aktøren har nære forbindelser til Norsk arbeidsgiverforening og støttes også økonomisk av kunnskapsdepartementet. UE tilbyr både materiell og kurs. Spesielt nevnes kursopplegg innenfor etablering av elev-, ungdoms- og studentbedrifter. Både arbeidsgiverorganisasjonene og arbeidstakerorganisasjonene innenfor næringslivet støtter aktiviteter som tilrettelegges innenfor entreprenørskapsfeltet. Blant aktører som ønsker å fremme sin sak er miljøvernorganisasjonen LOOP som tilbyr gratis materiell for skoler innenfor miljøvern. Nevnes bør også et prosjekt som «Nysgjerrigper» som drives av Norges forskningsråd med sikte på å fremme interessen for - i samarbeid med skoler - idèutvikling, utprøving og forskning blant barn.

I Sverige ser vi også mange av de samme aktørene som i de øvrige landene i Norden. Men i Sverige har NUTEK hatt en sentral rolle. Her må 0020«Verket før næringslivsutvikling» spesielt nevnes. Young Enterprise er en av de aktive eksterne aktørene også i Sverige. Konseptet som følges der er i hovedsak det samme som nyttes internasjonalt, men med tilpasninger til forhold i det aktuelle landet. Det må tas med at «Innovasjon Sverige» også er en av de eksterne aktørene som interesserer seg for temaet entreprenørskap.

\subsection{Enkeltstående eksempler på tiltak}

Det nevnes kun noen enkeltstående tiltak i denne sammenfatningen som svar på mandatets neste punkt.

- Kartlegge vellykkede tiltak for kreativitet, innovasjon og entreprenørskap i opplæringen/undervisningen!

Det er omtalt eksempler på tiltak som vurderes som vellykkede i rapportene fra hvert enkelt land. Noen av disse tiltakene er vurdert og beskrevet relativt detaljert, andre nevnes mer summarisk. Her velger vi kun å referere 
til et lite utvalg av tiltak - ett eksempel fra hvert land - som er beskrevet For øvrig henviser vi til hovedkapitlene for nærmere gjennomgang.

Fra Danmark trekker vi spesielt fram kaospilotutdannelsen (pkt 1.9) som representerer mange av de kvalitetene som kjennetegner entreprenørskap. Innovasjon og kreativitet er koblet til evnen å håndtere kaos samt virksomhet som er lekende, virkelighetsnær, risikotolerant, balansert og opptatt av menneskelige problemer på alle plan, medfølelse og sosial ansvarlighet. Ord og begreper som kjennetegner entreprenøriell pedagogikk.

Fra Finland trekker vi fram hvordan man på Åland fokuserer på temaområdet «medborgarskap» innenfor entreprenørskapssatsingen. Her vektlegges grunnleggende etiske verdier og normer for å etablere et samfunn (pkt 3.3.2). Slike verdier er fundamentale etter som entreprenørskap på lengre sikt handler om å fostre (eller danne) det entreprenørielle medansvarlige mennesket. Danningsprosessen står i sentrum.

Fra Island trekker vi fram Kirkaskóli som ligger i en forstadskommune til Reykjavik. Denne skolen har arbeidet med å utvikle en enhetlig skole for barn mellom 1 og 10 år. Formålet har vært å viske ut overgangsvansker mellom barnehage og skole. Fysiske rammer, så vel som innhold, har fått en utradisjonell utforming. Det ser ut til å bli svært vellykkede resultater av dette innovative skoleutviklingsprosjektet. Her skapes en ny entreprenøriell skole gjennom utvist pedagogisk entreprenørskap.

Eksemplet som er beskrevet fra Norge er et prosjekt Nordland fylkeskommune har gjennomført for hele fylket. Prosjektets mål var å få større innovativ aktivitet i gang i fylket (amtet) - «Et Nordland som syder og koker» var prosjektets navn. Tiltak på alle nivå i utdanningssystemet ble realisert i dette prosjektet. Dette prosjektet ble formelt evaluert av Kunnskapsparken i Bodø (KPB). Resultater fra denne evalueringen er også formidlet $\mathrm{i}$ kapittel $4 \mathrm{i}$ denne rapporten.

Fra Sverige nevnes «FramtidsFrøn», etablert i 2004 som en ideell forening der medlemmene er kommuner og skoler. Hensikten er å styrke barns selvtillit og naturlige tiltakslyst. Formålet er ut over dette å hjelpe skoler til å arbeide mer entreprenørielt gjennom ulike program (1-9 klasse). Det nasjonale prosjektet «Finn upp» inngår som en del av dette prosjektet. «Finn upp» skal identifisere folks hverdagsproblemer og finne løsninger på disse problemene.

\subsection{Eksempler på globale problemstillinger - konkrete utfordringer}

- Globaliseringens utfordringer

Globaliseringsperspektiv har vært trukket inn og nyttet som referanser i studiens innledning og i diskusjon av studiens funn flere steder i dette sammendraget. I denne studien er det bare noen aktuelle tema som kan 
nevnes, i hovedsak begrenset til generelle problemstillinger av betydning for Norden. Vi vil gi noen eksempler på konkrete problemstillinger som understreker hvordan globale, nasjonale, lokale og individuelle utfordringer og handlinger henger sammen. Med utgangspunkt i dette omtales noen områder som utfordrer oss globalt og som fortsatt bør mobilisere pedagogisk entreprenørskap.

Den verdensomspennende økonomiske krisen som startet i 2008 preget også stekt året 2009. Vi finner eksempler på mikrofinans prosjekter innenfor sosialt entreprenørskap etablert ved Universitetet i Oslo og relatert både til fattigdomsproblemet og til den økonomiske krisen. Dette gjelder både små prosjekter som skoleklasser driver og større prosjekt.

Kreativitet realisert gjennom skapende virksomhet er den langsiktige ressursen det må satses på dersom samfunnet skal ha mulighet til å etablere arbeid for alle. Derfor er etablering av ny virksomhet så viktig. Og det enkelte mennesket kan som deltakende aktør og entreprenør selv være med å bidra i å skape dette fremtidssamfunnet. Globale utfordringer forutsetter at vi har innovative organisasjoner i Norden - herunder innovative barnehager og skoler - og innovative mennesker som leder og driver disse organisasjonene. Utviklingen krever spesielt at den grunnleggende ressursen - de kreative menneskene - ser behovene, at de vurderer mulighetene dette gir for ny virksomhet, og at de selv og fellesskapet gjør noe med det.

Det registrer også at det gjennomføres en del prosjekt i grunnopplæringen relatert til miljø- og klimaproblematikk, men sett i forhold til den globale betydning og politiske vektleggingen nasjonalt og globalt kan man neppe si at det utvises spesielt stor grad av kreativitet. Det er imidlertid riktig å si at det skjer en hel del på dette feltet. Her er det rom for at utdanningssystemet i større grad utviser entreprenørskap basert på lokale forhold, men med globale perspektiv som referanse.

Problemstillinger som angår innvandring og flyktningers situasjon er aktuelle de fleste stedene i Norden. Dette har betydning for mange skoler og lokalsamfunn. Andre tiltak kan også trekkes fram som konkrete eksempler på hva globaliseringen kan føre med seg, jfr. håndteringen av svineinfluensaepidemien for ett par års tid siden.

For mange elever dropper ut av den grunnleggende opplæringen. Mange skoler utviser stor entreprenøriell aktivitet og skaffer seg erfaringer med alternative måter å organisere læringen på. Elev- og ungdomsbedrifter er viktige virkemiddel som kan brukes aktivt for å redusere frafall. Slike læringsbedrifter har særlig stor motiverende betydning, og bidrar til en aktiv handlingsorientert læring som er meningsfull for elevene. Det er gjennom nærhet og tett oppfølging av elevene i meningsfylte læringssituasjoner at skolen selv, lærere og elevtjenesten kan bidra for å redusere frafallet spesielt i videregående skole (ungdomsutdanningen). 


\subsection{Noen råd om nordisk samarbeid}

Koordineringsgruppa er også bedt om å påpeke konsekvenser av behov for entreprenørskap og å utlede noen konsekvenser av studien, eventuelt påpeke områder der det er behov for ny satsing og nye initiativ. Spørsmålsstillingen er slik:

- Konsekvenser, ny satsing og nye initiativ? Påvisning av behov for entreprenørskap?

Koordineringsgruppen for denne studien foreslår at det realiseres et mindre antall tiltak som det kan være realistiske å be NMR om å være med å initiere videre.

\subsubsection{Forslag til tiltak}

\section{Begrepsdefineringen}

Det er fremdeles nødvendig å arbeide for å avgrense og definere forståelsen av likheter og forskjeller mellom innholdet i begrepene «entreprenørskap» og "pedagogisk entreprenørskap». Entydige definisjoner kan være avklarende og vil være et viktig bidrag til å videreutvikle innhold og arbeidsmåter innenfor pedagogisk entreprenørskap.

Tidsskrift

Pedagogisk entreprenørskap vil som eget faglig - vitenskapelig forskningsfelt ha behov for et tidsskrift som muliggjør kollegial og faglig formidling. Norden vil utgjøre et naturlig område for et eget tidsskrift. Foreløpig drøfting med aktuelle samarbeidspartnere på forlagssiden viser at det er grunnlag for et slik nytt nordisk tidsskrift. Det trengs noe økonomisk startstøtte for å få etablert et slikt tidsskrift.

\section{Mastergrad}

Et samarbeidsprosjekt mellom nordiske universitet/høgskoler der det tas opp en mastergradsgruppe innenfor pedagogisk entreprenørskap sammensatt av studenter fra de nordiske landene. Koordineringsgruppen har diskutert en mulig modell for et slikt samarbeid. Tiltaket vil kunne fremme nettverksbygging og nordisk samarbeid. Et initiativ fra NMR, evt med stipendieordninger, kan være aktuelle incitamenter. Gjennom et slikt tiltak vil også kompetanseutvikling på alle nivå aktualiseres, fra bachelor til $\mathrm{PhD}$ nivå.

\section{Nordisk samarbeid}

Et nordisk samarbeid er allerede initiert av NMR ved etablering av denne studien. Dette samarbeidet har uten tvil hatt sin egenverdi, men kan også være en kime til videreutvikling av dette fagområdet. Samarbeidet bør 
derfor fortsette etter at utredningsarbeidet er gjennomført. Forskningsgruppen tilrår NMR å diskutere mulighetene for å videreutvikle samarbeidet, gjerne ved etablering av nordiske forsknings- og kompetanseutviklingsprosjekt.

Nordisk forskningskonferanse - pedagogisk entreprenørskap

En forskningskonferanse ble etablert i 2008, med Høgskolen i Bodø som initiativtaker. Dette initiativet bør videreføres idet det er et viktig grunnlag både for tidsskriftet og for videreutdanning på mastergrads, evt. PhD nivå.

Her følger noen forslag til generelle styrkingstiltak basert på behov som er registrert. Nedenfor trekkes noen hovedmomenter fram. Dette gjelder tiltak som er aktuelle i hele Norden.

\section{Etter- og videreutdanning}

I de nordiske landene er det flere aktører som tilbyr kurs og etterutdanning relatert til entreprenørskap, men slike kurs er vanligvis kortvarige og utgjør ikke en sammenhengende helhet. Ved noen lærerutdanningsinstitusjoner i Norden er det etablert mer omfattende tiltak, men i begrenset omfang. Det er imidlertid behov for å gjennomføre lcererutdanningstiltak innenfor pedagogisk entreprenørskap i hele Norden. Begrepet entreprenørskap assosieres vanligvis med etablering av forretningsmessig virksomhet. I pedagogisk sammenheng er det imidlertid behov for å klargjøre fundamentet i forståelsen av hva det vil si å være entreprenøriell, og hvordan dette henger sammen med utvikling av kreativitet og innovativ kapasitet både på individuelt og organisatorisk nivå. Slike tiltak vil måtte variere med hensyn til innhold og omfang. Dette utvalget foreslår at det utveksles erfaringer mellom tilbyderne av etter- og videreutdanning for lærere både innenfor hvert land, og på tvers av landene i Norden. Nettverk mellom pedagogiske institusjoner kan gjerne etableres for å ivareta denne type spredningsvirksomhet. På dette området vil det kunne utvikles spennende prosjekt. Og det vil også kunne påvirke til utvikling av et nordisk forskernettverk.

\section{Vitenskapelig forankring}

En entreprenøriell pedagogikk legger stor vekt på læring gjennom tilegnelse av erfaringer. Dette er en handlings- og erfaringsbasert pedagogikk. Det er behov for å holde fast på dette blant annet ved å tilby etterutdanningsvirksomhet der grunnleggende pedagogiske og didaktiske problemstillinger diskuteres. I en slik sammenheng vil det være mulig å utvikle forståelsen av hva pedagogisk entreprenørskap betyr som kortsiktige opplæringstilbud og som bidrag i den pedagogiske dannelsen på lang sikt. 


\section{En rød tråd}

Det fremheves ofte at opplæring til entreprenørskap skal gå som en «Rød tråd» gjennom hele utdanningssystemet fra førskole til høgskole. Fremtidens etablerere formes allerede gjennom å vektlegge kreativ og innovativ påvirkning gjennom dannelsesprosessen som starter i førskolealderen. Men innholdet i entreprenørskapsopplæringen må selvsagt være svært forskjellig avhengig av aldersnivå og læringskontekst. Dette betyr at en overordnet forståelse av hva ulikhet (og likhet) i en entreprenøriell dannelse skal innebære er viktig når dette gjelder opplæring av små barn contra opplæring av voksne som skal etablere seg med egen virksomhet? Det er derfor behov for å utforme en entreprenøriell pedagogikk som klargjør hva det betyr på lengre sikt å påvirke barn og unges «mindset», kontra det å tilrettelegge kortsiktig etablereropplæring for voksne.

\section{Forskningsbasis}

Utvikling av en entreprenøriell pedagogikk må også bety utvikling av et vitenskapelig grunnlag for dette temaet. Forskningsprosjekt bør kunne etableres både gjennom nasjonale tiltak og ved etablering av et nordisk program Programutvikling foreslås etablert i samarbeid med aktuelle forskningsråd eller andre nasjonale koordineringsinstanser, gjerne departement eller direktorat. Utvalget foreslår at NMR tar initiativ til dette.

Redusere frafall ved bruk av elev-og ungdomsbedrifter

Det er mulig gjennom elev- og ungdomsbedrifter å skape engasjerende, motiverende og meningsfull opplæring av elever som er i faresonen for å droppe ut av utdanningssystemet. Systematisk bruk av slike tiltak med tilrettelagt oppfølging og evaluering tilrås utprøvd i større omfang i hele Norden.

\section{Ledelse og virksomhetsplaner}

Strategien med bruk av nasjonale planer utarbeidet tverrdepartementalt i med sikte på å fremme entreprenørskap - herunder kreativitet og innovasjon - i de nordiske landene representerer et «top-down» perspektiv på hvordan skoleutvikling kan initieres. Men et slikt perspektiv må bli svært langsiktig og vanskelig å få hurtig effekt av dersom det ikke følges opp med konkrete tiltak, handlinger og aksjoner utviklet lokalt. Manglende oppfølging får som konsekvens at lite skjer. Realiseringen av denne strategien i kombinasjon med en «down-top» strategi, bør derfor være naturlig å ta i bruk for å styrke implementeringen. Dette kan gjøres ved å forplikte ledelsen på institusjonsnivå (barnehage, skole) til å utvikle og realisere egne institusjonsplaner og tiltak. Lederne lokalt (rektorer, styrere, eierne) vil være i nøkkelstillinger ved en slik videreutvikling av strategien. 
Spredningssystem - nettverk

Det bør vurderes hva slags spredningsmetoder som kan tas i bruk for å få ut informasjon om opplæringsmyndighetenes intensjoner med å vektlegge pedagogisk entreprenørskap i utdanningssystemene. Slik informasjon kan selvsagt gis gjennom direktiver, men selve temaet utfordrer hver enkelt lærers innsikt i begrepet og arbeidsområdet. Man kan tenke seg ulike modeller for kunnskapsspredning i de nordiske landene. Her synes det å være nødvendig med et forpliktende samarbeid mellom lærerutdanningsinstitusjonene og ansvarlige myndigheter for kompetanseutvikling i opplæringssystemet. Det bør utredes og vurderes grundigere om etablering av flere elektroniske nettsted kan være en måte å spre kunnskap på. I denne studien er det flere ganger poengtert at utviklingen foregår parallelt - og med stor likskap - i Norden som helhet. Utvikling av flere nettsted, samt andre alternativ, må vurderes også med sikte på å finne fram til rasjonelle systemer som kan betjene Norden som helhet.

\section{Skoleprosjekt}

Å satse på pedagogisk entreprenørskap må i særlig grad bety at hele skolesystemet bygger opp gode forbindelser til det omkringliggende samfunnet; næringslivet, kulturlivet, sosiale institusjoner og anvender disse aktivt i undervisnings- og læringsarbeid. Derfor trenger skolen samspill med entreprenører i næringsliv, kulturliv og ideelle organisasjoner. En betydelig satsing på dette kan være det viktigste bidraget som må gjennomføres blant annet for å få elevene til å se betydningen av utdanning. Dette er nødvendig på alle nivå for å sikre at elevene lærer på en meningsfylt, aktiv og motiverende måte. Alle land i Norden tilrådes å satse på slik prosjektutvikling som følges aktivt opp for blant annet å utvikle og spre kunnskap. Slike prosjekt kan med fordel tilrettelegges som aksjonsforskningstiltak i samspill mellom grunnopplæringen (ungdomsutdanningen), høgskole og universitet.

\section{Lærerkurs}

Det må etableres spesifikke kurs for lærere i den grunnleggende lærerutdanningen og som etter- og videreutdanning:

- Kurs som fokuserer på hva kvaliteten i læringen vil bli når kursene endrer fokus fra foreskrivende til undersøkende/eksperimenterende arbeidsformer

- Kurs der innovasjon og entreprenørskap kobles sammen

- Kurs der kreativitet og entreprenørskap er de sentrale elementene 


\title{
2. Praktisk-musiske fag $\mathrm{i}$ utdanningssystemene i Norden
}

\author{
Sammenfatning (tilleggsstudie 1) \\ Lise-Kari Berg og Gerd Abrahamsen
}

\subsection{Innledning}

Kartleggingen av de praktisk estetiske ${ }^{7}$ fagene i utdanningssystemene i de nordiske landene tar for seg følgende spørsmål:

- Hva menes med praktisk musiske fag8 i de nordiske landene? Hvilke fag gjelder dette og hva slags innhold og omfang har fagene? Undersøkelsen bør avdekke likheter og forskjeller i begrepsbruk $i$ planverkene og klargjøre om fagbegrepene i det hele tatt brukes. Undersøkelsen bør avdekke innovative trekk i fagutviklingen.

- Hvordan vektlegges kreativ lcering i de praktisk musiske fagene og hvordan arbeider elever og lcerere med kreativitet, innovasjon og entreprenørskap i fagene?

- Hva slags etterutdanningstilbud får læerere mht kreativitet og innovasjon i praktisk musiske fag?

- Hva slags rolle har de praktisk musiske fagene i forbindelse med satsing på entreprenørskap?

- Andre momenter

Undersøkelsen bygger i hovedsak på analyse av læreplaner for ulike utdanningsnivå og har sin hovedtyngde innenfor grunnskolen (folkeskolen). I noen tilfeller framkommer det også opplysninger om kreativitet, innovasjon og entreprenørskap i barnehage, videregående opplæring og lærerutdanning. Sammenfatningen er strukturert etter spørsmål 1-5 ovenfor. I tillegg ser vi på innholdet i begrepet kreativitet ut fra de praktisk estetiske fagenes ståsted. Til slutt presenteres en rekke forslag til tiltak som kan styrke kreativitet, innovasjon og entreprenørskap i de nordiske utdanningssystemene.

\footnotetext{
${ }^{7}$ Den norske betegnelsen på faggruppa brukes i sammenfatningen

${ }^{8}$ Den danske betegnelsen på faggruppa brukes i oppdragsteksten
} 
For hvert land er det redegjort for de fagnavnene og gruppebetegnelsene som brukes. Det finnes en detaljert oversikt over dette i rapporten fra hovedstudien. Her følger en kortfattet og konsentrert gjennomgang:

- Hva menes med praktisk musiske fag i de nordiske landene? Hvilke fag gjelder dette og hva slags innhold og omfang har fagene?

Praktisk estetiske fag er en sammensatt faggruppe hvor fagnavn og fagkombinasjoner varierer, ikke bare landene imellom, men også etter hvilket nivå i utdanningssystemet de befinner seg på. Utgangspunktet som er gitt i oppdraget, tar utgangspunkt i en faggruppe som i Danmark kalles praktisk musiske fag og omfatter idrett, musikk, bildekunst, håndarbeid, sløyd og hjemkunnskap i folkeskolen. På Grønland brukes samlebetegnelsen «lokale valg» om fagene håndverk og design, kunst og arkitektur, idrett og uteliv, sang, bevegelse og drama. De finske fagbetegnelsene er tilnærmet de samme, men faget huslig økonomi erstatter heimekunnskap og idrett kalles i Finland gymnastikk. Også i den islandske grunnskolen er fagbetegnelsene nesten identiske med de som brukes i Danmark. Ungdomsutdannelsen inneholder faggrupper som kunstfag og idrett. I Norge er kunst og håndverk ett fag, mens mat og helse tilsvarer det danske faget hjemkunnskap. I den svenske grunnskolen benyttes ikke en felles fagbetegnelse som tilsvarer praktisk musiske eller praktisk estetiske fag. De svenske fagene heter idrett og helse, musikk, bilde, sløyd og hjem- og konsumentkunnskap. Fagene ble tidligere omtalt som estetisk-praktiske.

På andre nivå i utdanningene kan fagene ha andre navn. I alle de nordiske landene er man godt kjent med hvilke fag det er tale om og man benytter gruppebetegnelser (praktisk estetiske, praktisk musiske, estetiskpraktiske) som har vært brukt eller fortsatt brukes. Samlebetegnelsene oppleves tilsynelatende som problematiske i noen av landene, kanskje fordi disse fagene over tid har fått sterkere fagidentitet og ikke i så sterk grad som tidligere kan betraktes som instrumentelle i forhold til mål i andre skolefag og andre formål. Det ser også ut som om faggruppa i flere land oppleves som lite ensartet. De estetiske fagene, kunstfagene, har en sterkere felles identitet enn det vi mener med praktisk estetiske fag når vi inkluderer kroppsøving/idrett og mat og helse/hjemkunnskap.

Når vi ser på omfanget av det samlede timetallet som er satt av til faggruppa praktisk estetiske fag, viser det seg å være nokså likt i de nordiske landene. Nær $25 \%$ av det samlede timetallet (Island 26,6 \%, Sverige 21,5 \%, Norge og Finland $25 \%$, Danmark minimum (1500 timer $+120 \mathrm{t}$ til valg $=$ ca 23,5 \%). Spesifikasjoner finnes i tabellen i vedlegg 1 . Sammenligninger er ikke mulig på andre utdanningsnivå som følge av svært ulik programstruktur og valgmuligheter. 
- Hvordan vektlegges kreativ læring i de praktisk musiske fagene og hvordan arbeider elever og lærere med kreativitet, innovasjon og entreprenørskap i fagene?

Spørsmålet indikerer at både planer og praksis undersøkes, men studien ble pga stram tidsressurs avgrenset til å fokusere bare på plananalyser. Når det likevel finnes noen beskrivelser og synspunkt om praksis i nasjonsstudiene, er de basert på forfatternes allmenne kjenneskap til og erfaring fra praksisfeltet. Dette kommer fram i de enkelte nasjonsrapportene.

\subsection{Begrepene kreativitet, innovasjon og entreprenørskap}

Undersøkelsens tre begreper blir til en viss grad definert i nasjonsstudiene. Kreativ og skapende forstås og anvendes som synonymer, mens fantasi ansees som en forutsetning for kreativitet. Det hevdes både at kreativitet for det meste knyttes til individets personlighetsdannelse og at kreativitet gjerne er et middel og ikke et mål i skolesammenheng. Et sted defineres begrepet til det å skape nye ideer og la tankene gå i nye baner, mens det fra andre forfattere påstås at det forutsettes anvendelse av ideer og faktisk handling om noe skal kunne kalles kreativt.

Innovasjon forstås også på ulike måter. Et sted framholdes det at innovasjon forutsetter eksperimentering, et annet sted at innovasjon kommer fram i interaktiv handling. I den islandske rapporten blir det vist til Oslo Manual (OECD 2005) der innovasjon defineres som en implementering av et nytt eller forbedret produkt, en ny og mer utviklet prosess eller forbedret metode. Mens kreativitet handler om person eller individ, er innovasjon nærmere forbundet med samfunnsmessige og økonomiske interesser, nye tilnærminger. Det hevdes også i en av rapportene at innovasjon, og også kreativitet, er kontroversielle begrep.

Når det gjelder begrepet entreprenørskap, forholder forfatterne seg i stor grad til offisielle definisjoner som den danske «med entrepreneur menes en innovativ person, der starter egen virksomhed» og det norske «(...) identifiserer økonomiske muligheter og gjør noe med dem ved å omforme ideer til praktisk og målrettet aktivitet (...)» I Sverige og Finland brukes «företagsomhet», Island har ikke oversatt begrepet, men bruker innovasjon og iverksetting i stedet for dette.

\subsection{Læreplananalysene}

Analysen av planene for dansk folkeskole viser at det er gitt plass for aktiv og skapende virksomhet, eksperimentering og uttrykkshandlinger i alle fag unntatt idrett. I lærerutdanningen er fagene sløyd og håndarbeid nylig slått sammen til et nytt fag, materiell design, hvor forståelse av 
begrepene kreativitet, innovasjon og bæredyktighet er et av de sentrale kunnskaps- og ferdighetsområdene, mens begrepet entreprenørskap ikke blir brukt. Det nye faget er resultat av regjeringens satsing på faggruppa i Danmark. Planene for lokale valg på Grønland viser ikke i samme grad vektlegging av begrepene vi her ser etter.

Analysen viser at i finsk skole fremmes kreativitet, innovasjon og företagsomhet på mange måter i læreplanene for denne faggruppa, men det påpekes at det er for få uketimer i fagene og at for få elever har mulighet til å velge fagene. Den islandske rapporten påpeker at faggruppa dekker en firedel av undervisningstida, og at den dermed er godt ivaretatt kvantitativt. Det kvalitative, bl.a. i form av lærernes kompetanse, er også en avgjørende faktor. Dette blir tydeligere etter hvert som fagene favner videre og stiller økende krav til kompetansen hos dem som underviser. Faget sløyd og design har eksplisitt vektlegging av kreativitet og innovasjonsprosessen, også med en digital dimensjon.

Det norske planverket har i den overgripende generelle delen, som gjelder for hele utdanningsløpet, et eget kapittel om «Det skapende menneske» som skal forplikte til å arbeide med kreativitet og skapende tenking og virksomhet i alle fag. Planene for det enkelte praktisk estetiske fag i grunnskolen har varierende vektlegging av kreativitet, innovasjon og entreprenørskap. Musikk og kunst og håndverk betoner dette sterkere enn kroppsøving og mat og helse. I de svenske læreplanene er det gjort tilsvarende funn som indikerer at de visuelle og auditive kunstfagene har mer oppmerksomhet rettet mot kreativitet enn idrett samt hjem- og konsumentkunnskap. Sløyd trekkes fram som et godt eksempel på et «företagsomt skolämne», mens det forholdsvis nye faget teknikk (1994) kunne vært et slikt foretaksomt emne, men ikke helt ser ut til å fungere slik i praksis. Den svenske rapporten tar også opp manglende lærerkompetanse som problemstilling.

- Etter- og videreutdanningstilbud med satsing på entreprenørskap

Danmark, Finland og Island: Rapportene omhandler ikke etter- og videre- utdanningstilbud. I vår studie har det ikke vært mulig å finne gode og pålitelige data, men det er nærliggende å anta at dette reflekterer ingen, eller meget svak, satsning på slik kompetanseutvikling. Her er det behov for flere spesifikke undersøkelser og tiltaksutvikling.

Norge: I Norge skilles det mellom etterutdanning og videreutdanning. Videreutdanningskurs omfatter arbeidskrav og eksamen. Dette gir studiepoeng og dermed formell kompetanse. Etterutdanning er kortere kurs som ikke gir formell kompetanse. Undersøkelse av nettsidene til høgskoler og universitet viser at det tilbys svært få videreutdanningstilbud innenfor praktisk estetiske fag med særlig søkelys på entreprenørskap, mens etterutdanningskurs ikke kan spores på denne måten. 
Sverige: Den svenske bidragsyteren har ikke funnet kurstilbud for grunnskolelærere som retter seg mot det denne undersøkelsen omfatter. På høgskole og universitetsnivå finnes emnekurs innenfor lærerutdanningen. Men ingen av disse kursplanene er spesifikt rettet mot innovasjon og entreprenørskap, mens derimot kreativitet omtales på en uspesifisert, vag måte.

Etter-og videreutdanningsfeltet synes ikke å være prioritert $i$ Norden på en måte som viser at fagområdets betydning for å fostre entreprenørskap er erkjent. At denne studien ikke kunne avdekke og beskrive etterog videreutdanning innenfor praktisk estetiske fag kan selvsagt bero på manglende ressurser for å gjennomføre feltstudier. Men denne studien har avdekket at det kan være grunnlag for å gjennomføre en egen deskriptiv feltstudie.

- Praktisk musiske fags rolle i satsingen på entreprenørskap

Studiene fra de enkelte nordiske landene er også her resultat av dokumentstudier, undersøkelser på internett og generell kunnskap om spørsmålet. Noen av tiltakene har felles trekk med det som framkommer under punkt 3, siden lærernes etterutdanning er en viktig del av prosjektene.

I Danmark startet Undervisningsministeriet Pinonerutdannelse i 2009. Formålet er å utdanne lærere i kreativitet, innovasjon og entreprenørskap, men utdannelsen er ikke spesielt rettet mot praktisk estetiske fag. Fagene er likevel trukket inn gjennom deltakerprosjekt. Det er opprettet en idébørs i form av en kommunikasjonsplattform hvor ideer deles. Her finnes bl.a. eksempler på hvordan elever trenes i kreative prosesser. Ved de danske, regionale sentrene for undervisningsmidler (CFU) er det i 200910 ansatt innovasjonskonsulenter som skal bidra overfor folkeskolene. Lærere i praktisk estetiske fag er en selvsagt del av målgruppa, men ikke spesifikt. Prosjekter og kurs for lærere i praktisk estetiske fag benytter sjelden studiens tre begreper, men innholdsmessig omfatter de likevel nyskaping, gjenbruk og annen kreativ og innovativ virksomhet. Det nye faget materiell design kan også nevnes i denne sammenhengen - et fag som særlig satser på kreativitet, innovasjon og bæredyktighet.

Den finske studien trekker fram et lignende statlig tiltak som den danske Pionerutdannelsen. Utbildningsstyrelsen grunnla i 2007 KonstFärdprosjektet som skal fremme mangesidig og innovativ utvikling av kunstog ferdighetsdannelse i hele utdanningssystemet. Delprosjektene arbeider med ulike tema, og noen av dem kobler sammen innovasjon og kunstfag. Et annet eksempel på fremming av kunstfag i utdanningen er kultursenteret ARX-Tavastehus. Et pilotprosjekt i Savolax har som mål å utvikle innovativ kunnskap, og det finnes flere tilsvarende eksempler på prosjekt.

I Island finner vi faget sløyd og design, som er en arena for innovasjonsundervisning. I 1994 ble det utpekt en modell for innovasjon og kreativitet som utarbeidet en pedagogisk modell i samarbeid med Islands pedagogiske universitet. Denne modellen har siden slutten av 1990-tallet 
vært grunnlag og inspirasjon for mye av undervisningen i faget over hele landet. Det er elevenes egen kreativitet og innovasjonsprosessen som er styrende for undervisningen og ikke et spesielt faginnhold. Formålet er både elevens dannelse i form av utvikling av kreative evner, selvtillit og initiativ, men også prosessorientert undervisning og betydningen av kreativitet i dagliglivet, samt holdning til etikk og miljø. Den digitale dimensjonen er også tatt med.

Som i de øvrige nordiske landene er det vanskelig å finne satsing på entreprenørskap i Norge der initiativ og formålsbeskrivelser kommer fra de praktisk estetiske fagkretsene. Nasjonalt senter for kunst og kultur i opplæringen (KKS) ble opprettet i 2007 og har som hovedoppgave å støtte hele opplæringsfeltet i utvikling av kompetanse i estetiske fag. Senteret har også samarbeid med Ungt Entreprenørskap, som også samarbeider direkte med skoleverk og næringsliv. En tidligere kunnskapsminister la i 2009 fram ideen om å opprette et nytt fag i skolen som kunne kalles kreativitet. Ideen fikk ikke gjennomslag. I Norge finnes strategi- og handlingsplaner for entreprenørskap for hele utdanningssystemet.

Også den svenske rapporten viser til ulike prosjekt som ikke er spesifikt rettet mot eller initiert av praktisk-musiske fag. Prosjektene er ofte tematisk organisert og mulig å innpasse i forskjellige fag og emner. Det antas å variere sterkt om det faktisk gjøres. Eksempler på institusjoner, prosjekt og tiltak er Teknikens hus i Luleå, Föreningen FramtidsFrön, Entreprenørskap i skolan i Västerås kommune og Ung företagsamhet, som i likhet med det det norske Ungt Entreprenørskap har kobling til næringslivet.

- Forslag til tiltak

Her er først tekstene i de enkelte landenes studier sammenfattet punktvis i en tabell for å gi oversikt over hvilke tiltak som vektlegges land for land. De utfyllende tekstene i delrapportene vil selvsagt gi et mer utfyllende og nyansert bilde av forslagene. Deretter følger en tabell som sammenfatter de fleste av de foreslåtte tiltakene. 


\begin{tabular}{|c|c|}
\hline Land & Forslag til tiltak \\
\hline Danmark & $\begin{array}{l}\text { Satsing på de praktisk estetiske fagene med de verdier og egenskaper disse fagene } \\
\text { bidrar med i intellektuelle og personlige utvikling. De utvikler i seg selv kreativitet, inn- } \\
\text { ovasjon og entreprenørskap. } \\
\text { Oppheving av det uhensiktsmessige skillet mellom denne faggruppen og de øvrige } \\
\text { skolefagene. Understreke gjensidig berikelse og felles løft. } \\
\text { Innskriving av begrepene kreativitet, innovasjon og entreprenørskap i fagenes fagmål og } \\
\text { trinnmål for å øke bevisstheten hos folkeskolelærerne, } \\
\text { Integrere begrepene i plantekster og undervisningsforløp i lærerutdanningen. }\end{array}$ \\
\hline Finland & $\begin{array}{l}\text { Påpeking og synliggjøring av kunst-, ferdighets- og praktisk-fagenes kreative, innovative } \\
\text { og entreprenørielle handlingsstil og helheten fagene gir utdanning. } \\
\text { Forklaring av begrepene i læreplaner. } \\
\text { Satsing på fagkompetansen i disse fagene, og tilrettelegging slik at de lærerne som har } \\
\text { mest utdanning underviser på de øverste trinnene } \\
\text { Vektlegging av den spesifikke kunnskapen læreren som skal lære elever kreativitet, } \\
\text { innovasjon og entreprenørskap trenger. Mangfold av didaktisk etterutdanning } \\
\text { Forskningsbasert lærerutdanning. Samarbeid mellom naturvitenskapelige fag og kunst- } \\
\text { fag som kan gi nytenking og innovasjon. } \\
\text { Samordning av faglærerutdanning og klasselærerutdanning. }\end{array}$ \\
\hline Island & $\begin{array}{l}\text { Innovasjon og kreativitet må bli strategiske prioriteter (sett i lys av den økonomiske } \\
\text { krisen i Island). } \\
\text { Innovasjon og kreativitet som grunnleggende ferdigheter. } \\
\text { Tverrfaglig og problemorientert undervisning. } \\
\text { Synliggjøring av «good practie». } \\
\text { Styrking av medieundervisningen i praktisk estetiske fag. } \\
\text { Fokus på elevpresentasjoner. } \\
\text { Strategier for evaluering og vurdering i praktisk estetiske fag. } \\
\text { Samarbeid med private og selveiende institusjoner, f eks på musikk- og bildeområdet. }\end{array}$ \\
\hline Norge & $\begin{array}{l}\text { Kreativitet som grunnleggende ferdighet og «kjernekraft» i utdanningene. } \\
\text { Satsing på kreativitet for å skape et bredt entreprenørskapsbegrep. } \\
\text { Styrke den faglige lærerkompetansen i praktisk estetiske fag og forståelsen av kreativi- } \\
\text { tet. } \\
\text { Gjøre kreativitet og entreprenørskap tydelig i lærerutdanningene. }\end{array}$ \\
\hline Sverige & $\begin{array}{l}\text { Definere nøkkelbegrep og tydeliggjøre retoriske plantekster på alle nivå. } \\
\text { Kreativitet og nytenking koples til alle fag, ikke bare de praktisk estetiske } \\
\text { Entreprenøriell holdning utformes som en rød tråd gjennom utdanningssystemet. Ar- } \\
\text { beidsformer og problemformuleringer i de estetiske fagene kan danne modell for de } \\
\text { andre fagene. } \\
\text { Transparent bedømming og vurdering med kvalitetskriterier. } \\
\text { Samarbeide med entreprenører, kunstnere og andre utenfor skolen. } \\
\text { Styrke lærerutdanningen i estetiske fag og teknikk. }\end{array}$ \\
\hline
\end{tabular}

\subsection{Råd om tiltak}

- Økt satsing på forskning

Praksisnær forskning; utviklingsprosjekter som utformes I skolen.

Samarbeid mellom forskere og skoleverk.

Berede grunnen for et bredt vitenskapssyn som gir mange innfallsvinkler til kreativitet, innovasjon og entreprenørskap.

- Kreativitet som grunnleggende ferdighet. Kreativitet som «kjernekraft» Styrke kreativitetens plass i skolen - som forutsetning for all innovasjon.

Se på hvordan dette kan organiseres: implementeres i fag/på tvers av fag? Som eget fag? 
- Økt vekt på samarbeid på mange nivå/helhetstenkning Mellom faglærerutdanninger og «allmennlærerutdanninger», mellom barnehage, grunnskole, videregående skole og lærerutdanningen, mellom ulike skolefag og samarbeid de praktisk musiske fagene seg imellom. Mål: blant annet helhetstenkning: kreativitet, innovasjon og entreprenørskap som en rød tråd gjennom hele utdanningssystemet.

- Styrke lærerkompetansen

- Gi gode tilbud i både fagene og innenfor innovasjon og entreprenørskap tilpasset skoleverket. Her kan en blant annet trekke veksler på de praktisk-musiske fagenes vektlegging og kompetanse på kreativitet og elevaktive lærerprosesser.

- Tydeliggjøre begrepene i plantekstene.

Bevisstgjøring for lærere og studenter, samt signal om satsing på området.

- Ressurser. Øke timetallet og ressurser til praktisk estetiske fag for å imøtekomme etterspurt kompetanse.

- Etter- og videreutdanning. Det er nødvendig å satse bredt på utvikling av kreativitet som entre-prenøriell kjernekraft i grunnopplæringen. Dette innebærer opptrapping av etter- og videreutdanningstiltak innenfor praktisk-musiske fag. 


\title{
3. Utvikling av naturvitenskapelig talent og kreativitet i Norden
}

\author{
Sammenfatning (tilleggsstudie 2) \\ Espen O. Henriksen
}

På oppdrag fra Nordisk ministerråd presenteres her en kartlegging av hvordan de nordiske land arbeider med talentutvikling og kreativitet $\mathrm{i}$ grunnopplæringen i de naturvitenskapelige fag. Dette innledende sammendraget oppsummerer noen fellestrekk og kontraster mellom landene. Oppdragets forskningsspørsmål er brukt som overskrifter. Kildehenvisninger og referanser gjentas ikke i sammendraget, dette kan finnes i rapportene fra de enkelte land.

\subsection{Hvilke krav stilles i læreplanene om å ivareta talentutvikling?}

Det er vanskelig å drøfte og sammenligne landenes arbeid med talentutvikling i naturvitenskap uten en felles forståelse av hva som menes med «talent». Dreier det seg om spesielle talenter som bare finnes hos noen få, eller finner man talent hos alle? Her finner vi forskjeller mellom hvordan de nordiske land bruker begrepet i sine styringsdokumenter for skolen. Den norske læreplanen henviser flere steder til «talenter» som noe som finnes hos alle elever, og noe som alle har rett til å få utviklet videre i skolen. Ut fra denne forståelsen av talent kan man jo si at hele utdanningssektorens virksomhet dreier seg om talentutvikling. I Danmark dukket ordet «talenter» nylig opp i en ny forskrift for det danske gymnas, men da i sammenhengen «særlige tilbud til elever med særlige talenter». Med «særlig talent» henvises det til talent utover det alminnelige. Begrepet «særlige talenter» dukker også opp i norsk læreplan, der det under overskriften «Tilpasset opplæring» nevnes at også elever med «særlige evner og talenter» må få utfordringer å strekke seg mot. På svensk ser ordet «talang» ut til å ha lignende tolkningsmuligheter som det norske og danske «talent», men ordet er ikke å finne i svenske læreplaner. De islandske læreplanene omtaler heller ikke talentutvikling, og fra Grønland rapporteres det at det ikke har vært noen diskusjon om utvikling av talenter i naturfag.

Det kan være nyttig å skille mellom talentutvikling i vid forstand og i snever forstand. I vid forstand kan talentutvikling omfatte tiltak som bi- 
drar til å vekke og inspirere talenter hos elever som i utgangspunktet ikke var identifisert som talentfulle. I snever forstand kan talentutvikling forstås som tiltak rettet mot en liten gruppe som allerede er identifisert som talenter. Hva som er viktigst må sees i sammenheng med hvorfor man ønsker å satse på talentutvikling. I den svenske rapporten fremheves det at naturfagenes største problem er mangelen på interesse, at det er for få elever som ønsker å gå videre med naturvitenskapelige studier. Hvis man klarer å vekke interesse hos flere elever, så vil man også få rekruttert flere talenter til naturvitenskapelige studier. I rapportene fra de forskjellige landene gjøres det rede for både tiltak for talentutvikling i vid forstand og forsøk med talentutvikling i mer snever forstand, det vil si rettet mot et mindre antall utvalgte elever.

Når det gjelder talentutvikling i snever forstand så kan man se at det danske utdanningssystem skiller seg ut fra de øvrige nordiske ved at det $\mathrm{i}$ 2010 kom en ny forskrift som krever at det enkelte gymnas må etablere særlige tilbud til elever med særlige talenter. Det er også tallfestet hvor mange elevtimer den enkelte skole skal tilby innenfor denne ordningen.

\subsection{Talentaktiviteter}

- Hvilke tilbud av talentaktiviteter finnes der vektleggingen på ivaretakelse av tilbud til naturvitenskapelige talenter: nasjonalt, regionalt og/eller lokalt, undersøkes spesielt (eksempelvis talentaktiviteter som konkurranser, festivaler, camps, studiekretser m.v.).

Betydningen av «talentaktiviteter» avhenger selvsagt av hva man legger i begrepet «talent». Bruken av begrepskombinasjonen «naturvitenskapelig talent» er i all hovedsak et dansk fenomen. De andre nordiske landene har også i større eller mindre grad en debatt om undervisningstilbud som ivaretar elever med spesielle evner, men uten å definere en egen type talent knyttet til naturvitenskap. Det danske Mærsk Mc-Kinney Møller Videncenter (heretter «Talentcentret i Sorø») definerer for eksempel naturvitenskapelige talenter som «elever, som er gode til naturvidenskab og har mulighet for at blive blandt de bedste, hvis potentialet stimuleres.» Formålet med dette senteret er «at skabe et udviklingssted for særligt interesserede og talentfulde unge fra hele landet». Det er med andre ord åpenbart at dette senteret er opprettet for å drive talentutvikling i snever forstand.

Det samlede materialet fra de nordiske land illustrerer den store spennvidden av mulige modeller for talentutvikling i naturvitenskap. Innenfor talentutvikling i vid forstand finner man utenom den ordinære undervisningen et stort antall bredt anlagte konkurranser som er tenkt å stimulere interesse hos et stort antall elever. Alle nordiske land har diverse naturvitenskapelige konkurranser der elever kan delta med sine prosjekt. I forhold til talentutvikling må det påpekes at disse tiltakene er 
relativt kortvarige. Elever som viser spesielt talent vil typisk få en premie, men ikke nødvendigvis noen nye muligheter eller videre oppfølging.

Danmark skiller seg altså ut ved at det er opprettet ett nasjonalt senter for talentutvikling innen naturvitenskap (Talentcentret i Sorø). På Island utnyttes ordinære tilbud innen videregående skole til å gi ekstra utfordringer til grunnskoleelever. Dette skjer ved at enkelte grunnskoleelever får anledning til å ta moduler på videregående skoles nivå før de er ferdige med grunnskolen. I Norge åpner grunnskolefaget Utdanningsvalg for en lignende ordning, men det er ikke kjent om ordningen er tatt i bruk for faget naturfag.

De nordiske utdanningssystem er i all hovedsak offentlige. På Island finner vi imidlertid eksempel på tilbud til talentfulle elever i privat regi. Det private Reykjavik Universitet har siden 2007 drevet prosjektet Ad astra, der evnerike barn og unge i 6.-10. klasse tilbys naturfaglige (og andre) kurs mot betaling.

Et prinsipielt hovedskille mellom forskjellige offentlige tilbud til særlige talenter er om tilbudet gis i form av separate skoler/klasser, eller om de særlige talentene får tilbud om egne supplerende opplegg i tillegg til ordinær undervisning. Som eksempel på separate tilbud er det spesielt verdt å merke seg at det i Sverige i perioden 2009-14 drives forsøk med «spetsutbildning». Innenfor denne ordningen er det 10 gymnas som hver tilbyr 30 elevplasser i matematisk-naturvitenskapelig retning. Kanskje har man her overvurdert behovet for et slikt tilbud, i alle fall hadde de fleste av disse skolene mange ledige plasser i det første prosjektåret. Et lignende forsøk er under planlegging i Rogaland fylke i Norge, der to videregående skoler i Rogaland har lansert planer om egen linje for realfagtalenter. Et norsk regjeringsoppnevnt utvalg har også nylig foreslått opprettelse av minst fem realfagsgymnas, for elever med spesiell interesse og talent for realfag og teknologi.

De danske eksempler på forsøk med «snever» talentutvikling skiller seg ut ved at de ikke innebærer å segregere talentene i egne klasser/grupper. Talentcentret i Sorø tilbyr tidsbegrensede opphold for elevene, og de ønsker også å gjøre en innsats mot talentenes faste lærere. I København drives pilotprosjektet "Akademiet for Talentfulde Unge». Dette tilbudet gis til særlig motiverte gymnaselever på ettermiddagstid, en gang per uke.

De danske eksempler viser at talentutvikling ikke nødvendigvis må innebære nivådifferensiering, og det kan muligens være en fordel. I følge en kunnskapsoversikt fra det svenske Skolverket vil nivådifferensiering innenfor samme skole ha negativ effekt på elevenes kunnskapsnivå. I den norske debatten har det imidlertid vært hevdet at de mest evnerike elevene ikke kan finne seg til rette i vanlig norsk skole. Det dreier seg da om evnerike elever som opplever at det «ikke er lov til å være flink», de savner likesinnede, og det hevdes at disse elevene har både faglig og sosialt utbytte av å være i egne grupper. 


\subsection{Holdning til talentutvikling}

- Hva slags holdning har man i de nordiske landene blant lærere, skoleledere og politikere til at det tilrettelegges spesielle tilbud for talentene?

De nordiske lands læreplaner har et felles ideal om at den enkelte elev må få mulighet til å utvikle seg ut fra egne evner og forutsetninger. Det er dermed ingen tvil om at det ligger innenfor de nordiske skolers oppgave å la talentfulle elever få utvikle seg videre, på lik linje med elever som ikke er identifisert som «talentfulle». Men i følge svensk læreplan streber man også etter «att uppväga skillnader i barnens och elevernas förutsättninger att tillgodogöra sig utbildningen». Denne formuleringa antyder at forskjeller bør utjevnes, noe som selvsagt kan være problematisk hvis utjevningen oppnås ved at elever med gode læreforutsetninger ikke får utnyttet sine evner. I den finske rapporten understrekes det at begavede elever ikke skal opphøyes over andre elever, og det slås fast at «Det finns ingen grupp av elever i den finska skolan som skulle nämnas til talanger» (s. 37). Dessverre gir både den norske og den danske rapporten indikasjoner på at noen lærere mener det er feil å bruke spesielle ressurser på sterke elever, fordi dette vil øke forskjellene mellom elevene. En slik «likhetsideologi» vil kunne begrense utviklingen hos noen elever.

\subsection{Etterutdanningstilbud}

- Hva slags etterutdanningstilbud får lærere om å ivareta talentene?

Danmark skiller seg ut som det eneste landet som har lærerkurs med talentpleie som eksplisitt tema. Kursene er rettet mot folkeskolelærere og gymnaslærere og drives av Mærsk Mc-Kinney Møller Videncenter i Sorø.

\subsection{Kreativitet og innovasjon}

- Hvilken plass har kreativitet i naturvitenskapelige fag på ulike nivå og hvordan arbeider naturfaglærere med kreativitet og innovasjon?

I sammenheng med entreprenørskap og innovasjon er kreativitet gjerne assosiert med evnen til å lage nye og forbedrede produkter. De nordiske land har litt forskjellig faginndeling, og dermed er det ulike varianter av hvordan kreativ teknisk konstruksjon er knyttet til naturvitenskap. I Danmark har man faget Natur/Teknik fra 1.-6. klasse, i Sverige er «Teknik» et eget fag, mens man i Norge har innført «Teknologi og design» som nytt hovedområde innenfor faget «Naturfag» fra 2006. 
På læreplannivået er det forskjeller mellom de nordiske land når det gjelder i hvilken grad kreativitet fremheves eksplisitt. Begrepet kreativitet nevnes både i formålet for det norske «Naturfag» og i formålet for det danske «Natur/teknik», men har ikke noen tilsvarende sentral rolle i svenske eller finske læreplaner. Gymnaset på Åland skiller seg ut ved at kreativ problemløsning er vektlagt i læreplanene for alle de naturvitenskapelige fag. I den danske rapporten er det begrenset med informasjon fra Færøyene, men i den oversikten som gis er det ingen kobling mellom naturfag og begrepene innovasjon og kreativitet. Selv om det er forskjeller i eksplisitt bruk av begrepet kreativitet i læreplanene så kan det være forhastet å konkludere med at det dermed er tilsvarende forskjeller mellom landene i hvordan kreativitet vektlegges i undervisningen. I følge de nordiske læreplaner skal elevene lære ikke bare om naturvitenskapens teorier og begreper, men også om naturvitenskapelige arbeidsmåter. I naturvitenskapelig arbeid er det en forutsetning å være kreativ. Nye forklaringer oppdages ikke, de må skapes. Etter at en hypotese er konstruert trengs det kreativitet for å finne ut hvordan hypotesen kan etterprøves på best mulig måte. I naturvitenskapelige skolefag er det et klassisk problem at elevene ikke får anledning til å bli fortrolige med kreativitetens rolle i naturvitenskaplig forskning. Hvordan kan elevene i praksis får erfare kreativitetens rolle i naturvitenskapelig arbeid? Satsning på undersøkende arbeidsformer og prosjektarbeid skal blant annet bidra til at elever får erfare betydningen av kreativietet i naturvitenskapelig arbeid. I Norge har man valgt å tydeliggjøre betydningen av å lære om naturvitenskapelig arbeidsmåte ved at man i 2006 innførte et nytt hovedområde i naturfag «Forskerspiren» (ett av seks hovedområder i naturfag).

Fra et naturfagdidaktisk synspunkt er det viktig å få fram at kreativitet er viktig ikke bare for å utvikle produkter, men også for å utvikle og teste hypoteser. Spørsmålet er så i hvilken grad man kan lære spesifikt om kreativitet i naturvitenskap, eller om forståelse av kreativitetens betydning kommer inn naturlig som del av opplæring i undersøkende og naturvitenskapelige arbeidsmåter.

\subsection{Etterutdanning innenfor kreativitet og innovasjon}

- Hva slags etterutdanningstilbud får lærere mht kreativitet og innovasjon i naturfag?

Det er ikke funnet eksempler på etterutdanningstilbud rettet eksplisitt mot kreativitet og innovasjon i naturfag. Det må imidlertid understrekes at generell naturvitenskapelig og naturfagdidaktisk kompetanseheving vil bidra til å styrke lærernes metodiske repertoar og deres evne til å la elevene få jobbe utforskende og kreativt. Den svenske rapporten trekker 
fram et initiativ for skoler med årstrinn 1-5, «NTA (Naturvetenskap och Teknik för alla)», som skal ha styrket de kunnskapsbegrep som ligger til grunn for undersøkende og kreative arbeidsformer. 


\section{Avsluttende kommentarer og forslag til tiltak}

I dagens utdanningssystem har vi en spenning mellom det å «utdannes til spesialist» og det å «utdanne til medborgerskap». Mye tyder på at det første perspektivet i for stor grad preger skolen, slik at mye av undervisningen dreier seg om å «formidle ferdige fakta». Mange av de satsninger som gjøres for å styrke naturfag i Norden har som mål å øke andelen som velger å gå videre med naturvitenskaplig og teknisk utdanning. For å nå fram til flere av de som kan tenke seg til å bli spesialister trenger vi en holdningsendring til naturvitenskap og teknikk hos barn og ungdom. De unge bør få kunnskap om naturvitenskap og teknikk som er viktig for dem selv og for samfunnet. Det stereotype bildet av naturviteren og naturvitenskapen må endres. Det kan gjøres ved å undervise om naturvitenskapens egenart, dvs den naturvitenskaplige arbeidsmåten og hvordan naturvitenskap utvikles, samt naturvitenskap som menneskelig og sosial aktivitet, for å formidle tanker om at naturvitenskap er et fagområde der de fleste elever har tilstrekkelige talenter til videre utdanning og yrkeskarriere, samt at det er fordelaktig med kreativitet og innovative tanker for å bli en god naturviter.

Samlet sett gir de fem lands rapporter et mangfoldig bilde av hva talentutvikling i naturvitenskap kan være. Det savnes imidlertid dokumentasjon når det gjelder hva som er effekten av de forskjellige typer tiltak. $\mathrm{Vi}$ anbefaler at det gjennomføres en forskningsbasert evaluering av ordningene for spesielle talenter i Sverige og Danmark (spetsutbildning, timeressurs til talenter på gymnasene, og kurstilbudet i regi av Talentcentret på Sorø). Videre er det noen grunnleggende spørsmål som bør drøftes grundig for å avklare forutsetningene for videre satsning på talentutvikling innenfor naturvitenskap i de nordiske land:

- Hvordan bør satsningen fordeles mellom talentutvikling i bred og/eller snever forstand? (Hvilke elever skal nyte godt av talentutviklingsprogram, og hvordan skal de eventuelt velges ut?)

- Bør man segregere særlige talenter i egne grupper? Eller kan særlige talenter nyte godt av særlige tiltak uten å bytte elevgruppe, og uten å innføre nivådifferensiering?

Når det gjelder kreativitet og innovasjon så er det vanskelig å gi en generell vurdering av i hvilken grad disse begrepene er ivaretatt i den daglige undervisningen. Det er ingen tvil om intensjonen i fagplanene om at elevene skal lære om naturvitenskapelig arbeidsmåter. Spørsmålet er om 
elevene får erfare at kreativitet har en sentral rolle i naturvitenskapelig arbeid? En avgjørende faktor, som ikke er godt kartlagt, er i hvilken grad, og på hvilken måte lærerne i praksis tar i bruk undersøkende arbeidsformer. Utforskende og undersøkende naturfagsprosjekter stiller krav til skolenes utstyr og kompetanse. Behovet for kompetanse må sees i sammenheng med lærerutdanningene til de forskjellige lærerkategoriene. Lærerstudentene trenger både dybde og bredde innen naturvitenskap integrert med didaktikk. Dette er viktig for at kommende lærere skal få en stor verktøykasse med varierte arbeidsmåter som skaper interesse og motivasjon, for eksempel et dialogisk klasserom, drama, kollaborativ læring, undersøkende arbeidsformer samt tverrfaglige temaarbeid. Større utforskende prosjekt har vist seg å stimulere kreativitet. Kunnskap om naturvitenskapens karakter, som at naturvitenskapen utvikles gjennom eksperiment som kritisk granskes, antas å øke evnen til kreativ problemløsning. Et viktig aspekt for å utdanne for naturvitenskaplig kreativitet er at undervisningen må baseres på «hva naturvitere gjør» og «hvordan naturvitere gjør det», dvs at man må ha en undersøkende og eksperimentell tilnærming. Det er viktig å motarbeide bildet av at naturvitenskap bare er rasjonell tenkning, og i stedet løfte fram det kreative arbeidet.

For å oppnå dette er det viktig at innholdet i lærerutdanning og videreutdanning styres ut fra læreryrkenes behov, slik det gjøres i ingeniør- og legeutdanning, og ikke ut fra tradisjonelt innhold i de akademiske grunnkursene. Vi anbefaler derfor tiltak for å sikre at lærerne har den nødvendige naturvitenskapelige og naturfagdidaktiske kompetanse. I tillegg må det tas høyde for at utforskende og undersøkende naturfagsprosjekter stiller krav til skolenes materielle utrustning. En satsning på kreativt arbeid i naturfag forutsetter altså at skolene har tilgang til relevant undervisningsutstyr og egnede spesialrom. 


\section{norden}

\section{Nordiska ministerrådet}

Ved Stranden 18

DK-1061 København K

www.norden.org

\section{Kreativitet, innovasjon og entreprenørskap}

- Perspektiv på naturvitenskapelig talent og praktisk-musiske fag

De nordiske utdannings- og forskningsministre ønsker å fremme kreativitet, innovasjon og entreprenørskap i utdannelsene. Dette var bakgrunnen for at ministrene i april 2009 besluttet at Nordisk ministerråd skulle gjennomføre en nordisk komparativ studie av hvordan kreativitet, innovasjon og entreprenørskap er integrert i de nordiske utdanningssystemene.

Som tilleggsoppdrag til denne studien, ble det i 2010 under det danske formannskapet i Nordisk ministerråd, tatt initiativ til ytterligere to studier om henholdsvis de praktisk musiske fag og de nordiske lands arbeid med talentutvikling og kreativitet i relasjon til naturvitenskap.

Studiene er en del av Nordisk ministerråds globaliseringsprosjekt «En god opplæring til ungdom og voksne» som har som ett av fire delmål å fremme kreativitet, innovasjon og entreprenørskap i utdanningen.

Studiene er gjennomført under ledelse av Universitet i Nordland, Norge, på oppdrag fra Nordisk ministerråd. 